\title{
The 2017 Economic Impact of the Nebraska Agricultural Production Complex
}

\author{
by \\ Dr. Eric Thompson \\ Dr. Brad Lubben \\ Dr. Jeff Stokes
}




\author{
Prepared by \\ Eric Thompson \\ K.H. Nelson Professor of Economics and Director, \\ Bureau of Business Research, UNL \\ Brad Lubben \\ Extension Associate Professor and Director, \\ North Central Extension Risk Management Education Center, \\ Department of Agricultural Economics, UNL \\ Jeff Stokes \\ Professor and Hanson-Clegg-Allen Endowed Chair in Agricultural Banking and Finance, \\ Department of Agricultural Economics, UNL
}


Executive Summary

Table of Contents

Chapter 1 - Introduction 1

Chapter 2 - Industry Statistics within the Agricultural Production Complex.........................................4

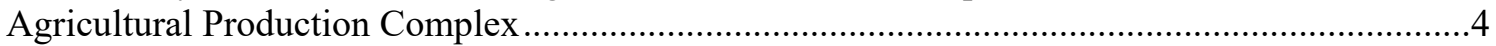

Figure 2.1 Backward and Forward Linked Industries for Corn Production ......................5

Figure 2.2 Backward and Forward Linked Industries for Beef Cattle Production .............5

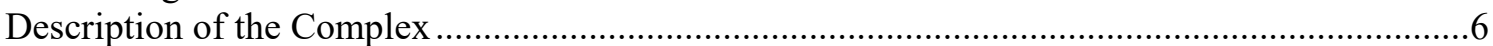

Table 2.1: Nebraska 2017 Crop Production for Selected Crops ......................................

Table 2.2: Nebraska 2017 Livestock Production ...............................................................

Table 2.3: 2017 Nebraska Sales in Agriculture-Related Manufacturing Industries ..........9

Table 2.4: 2017 Sales of Agriculture-Related Transportation and Wholesaling

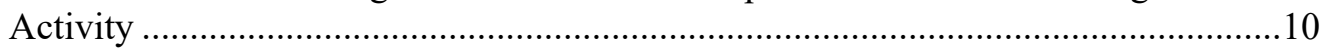

Table 2.5: 2017 Agri-Tourism Sales in Nebraska.....................................................10

Chapter 3 - Method for Evaluating the Economic Impact ...................................................................11

Figure 3.1 Approach for Calculating the Economic Impact of Industry with the

Agricultural Production Complex.........................................................................12

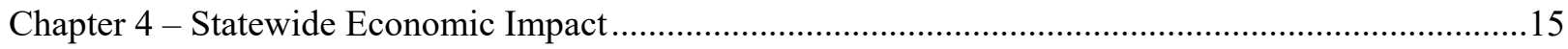

Statewide Economic Impact of Crop Production in Nebraska................................................15

Table 4.1A: 2017 Economic Impact (Business Receipts) of Crop Production

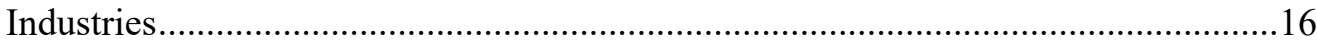

Table 4.1B: 2017 GSP (Value-Added) Impact of Crop Production Industries.................17

Table 4.1C: 2017 Labor Income Impact of Crop Production Industries ..........................18

Table 4.1D: 2017 Employment Impact of Crop Production Industries ............................19

Statewide Economic Impact of Livestock Production in Nebraska ...........................................19

Table 4.2A: 2017 Economic Impact (Business Receipts) of Livestock Production

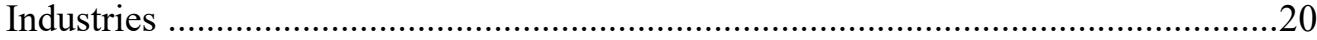

Table 4.2B: 2017 GSP (Value-Added) Impact of Livestock Production Industries .......21

Table 4.2C: 2017 Labor Income Impact of Livestock Production Industries ...................22

Table 4.2D: 2017 Employment of Livestock Production Industries...............................22

Statewide Economic Impact of Agriculture-Related Manufacturing in Nebraska ......................23

Table 4.3A: 2017 Economic Impact (Business Receipts) of Agriculture-Related

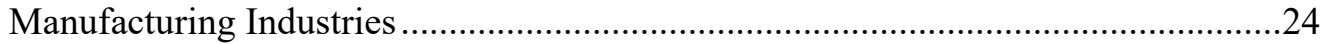

Table 4.3B: 2017 GSP (Value-Added) Impact of Agriculture-Related

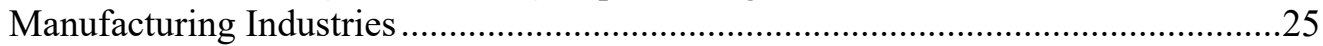

Table 4.3C: 2017 Labor Income Impact of Agriculture-Related Manufacturing

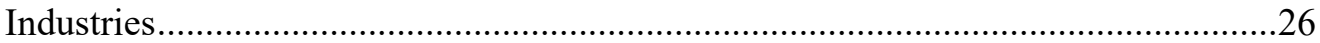

Table 4.3D: 2017 Employment Impact of Agriculture-Related Manufacturing

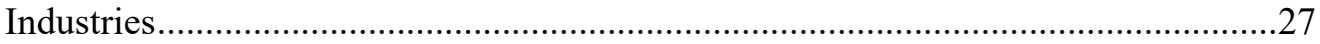

Statewide Economic Impact of Agriculture-Related Transportation and Wholesaling in

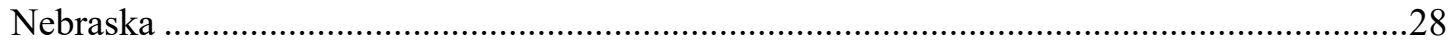

Table 4.4: 2017 Economic, GSP (Value-Added), Labor Income, and Employment Impact of Agriculture-Related Transportation and Wholesaling...............................28

Statewide Economic Impact of Agri-Tourism in Nebraska ......................................................28

Table 4.5: 2017 Economic, GSP, Labor Income and Employment Impact

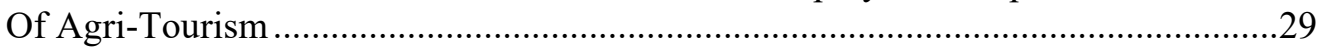


Summary of the Statewide Economic impact of the Agricultural Production Complex

Table 4.6: 2017 Economic Impact of the Agriculture Production Complex in Nebraska

Table 4.7: The Agricultural Production Complex's Share of the 2017 Nebraska Economy

Chapter 5 - Sub-State Economic Impact

Figure 5.1 Nebraska Sub-State Economic Regions

Figure 5.2: Agricultural Output (Business Receipts) as a Percent of Sub-State Regional Output - 2017....

Table 5.1: 2017 Economic Impact of Agriculture in Nebraska Output (Business Receipts) (Millions \$).

Table 5.2: 2017 Economic Impact of Agriculture in Nebraska -- Output (Business Receipts) by Region and by Crop and Livestock (Millions \$)....................................36

Table 5.3: 2017 Economic Impact of Agriculture in Nebraska Gross Regional Product (Value-Added) (Millions \$)

Figure 5.3: Agricultural Value-Added Volume as a Percent of Sub-State Gross

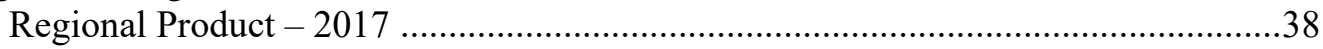

Figure 5.4: Agricultural Labor Income as a Percent of Sub-State Regional Labor Income - 2017

Table 5.4: 2017 Economic Impact of Agriculture in Nebraska - Labor Income (Millions)

Table 5.5: 2017 Economic Impact of Agriculture in Nebraska Employment.

Figure 5.5: Agricultural Employment as a Percent of Sub-State Regional Employment - 2017

Chapter 6 - Conclusions and Implications

References

Appendix 1

Table A.1.4.4A: Economic Impact (Business Receipts) of Agriculture Related

Transportation and Wholesaling

Table A.1.4.4B: 2017 GSP (Value-Added) Impact of Agriculture-Related

Transportation and Wholesaling....

Table A.1.4.4C: 2017 Labor Income Impact of Agriculture-Related Transportation and Wholesaling

Table A.1.4.4D: 2017 Employment Impact of Agriculture-Related Transportation and Wholesaling 


\section{The 2017 Economic Impact of the Nebraska Agricultural Production Complex}

\section{Executive Summary}

Nebraska is home to a large and diverse agricultural production complex involved in growing, processing, and transporting agricultural products as well as supplying agricultural producers. Included in this complex are: crop production, livestock production, agriculture-related manufacturing, transportation, and wholesaling, and agri-tourism.

This study has been conducted to provide a benchmark assessment of the economic impact of Nebraska agriculture on the state's economy. The impact is estimated for 2017, the year of the most recently completed Census of Agriculture. That Census provides detailed information on production, employment, and other activity in crop and livestock production.

The study relies on this Census data and the IMPLAN (IMpact analysis for PLANning) model. The IMPLAN model provides detailed information about state and local activity in manufacturing, transportation, and wholesaling, including information for the year 2017. The IMPLAN model is also able to assess how economic activity in a particular agricultural or agriculture-related industry ripples throughout the area economy. Such multiplier impacts are added to direct industry activity to yield the total economic impact. Total impacts can be estimated for multiple measures including total dollar output (business receipts), gross state product (a value-added measure), labor income, and employment numbers.

Both statewide and sub-state economic impacts are estimated for the agricultural production complex. Sub-state analysis is undertaken given the diversity of natural resource endowments, demographics, and transportation infrastructure within the state of Nebraska. The structure of the agricultural production complex varies throughout the state due to these factors.

\section{The Findings:}

The combined direct and multiplier impacts of the agricultural production complex account for a significant share of Nebraska's economy. For the year 2017, total dollar output (business receipts) was $\$ 81.8$ billion accounting for $33.9 \%$ of the state's total output, as seen in Figure ES.1. In terms of gross state product (analogous to gross domestic product, the broadest measure of the U.S. economy), the amount was $\$ 25.7$ billion which represents $21.6 \%$ of the state's GSP. Even in a year like 2017 with low commodity prices and modest farm incomes, between one-fifth and one-fourth of Nebraska's economy can be attributed to the agricultural production complex. Few other states have an economy with this degree of agricultural prominence.

The labor income and employment impacts also are significant. The labor income impact (proprietor income, wages, salaries, and benefits) of the complex was estimated to be $\$ 14.3$ billion in 2017 , or $19.9 \%$ of the Nebraska total. In terms of employment numbers, the complex accounted for 321,000 positions or $23.3 \%$ of Nebraska's total wage and salary and proprietor employment. Many of these positions are full-time, although part-time and seasonal employment at farms, ranches, or other businesses also are included. 


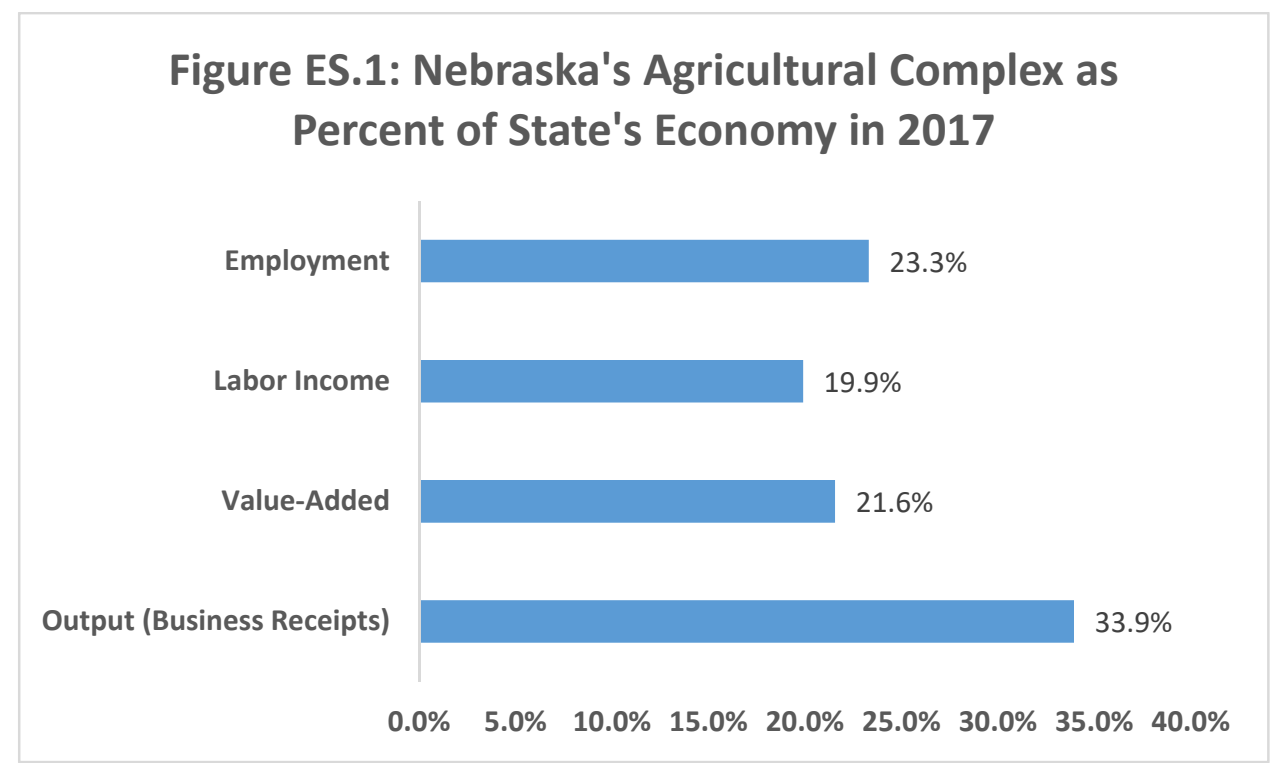

Within the state, Northeast Nebraska's regional economy is especially influenced by agriculture. Large volumes of both crop and livestock commodities are produced in the region along with agricultural inputs and processing activity. In Northeast Nebraska, the agricultural production complex accounted for $64 \%$ of industry output in 2017 and $46 \%$ of the region's gross regional product (value-added), while employing or supporting $48 \%$ of the region's workforce and $45 \%$ of its labor income. Agriculture's prominence also was quite high in the Central, North, South, and Southeast Nebraska regional economies where more than one-third of the gross regional product, labor income, and employment were agriculture-related in 2017. The agricultural product complex accounted for $23.9 \%$ of gross regional product in Northwest Nebraska and $20.7 \%$ in Southwest Nebraska. Finally, the East region of the state generated the largest regional dollar volume of agricultural activity and agriculture-related employment numbers. However, given the presence of the state's two largest urban centers, agriculture's portion of the East region's broader-based economy was smaller, but still quite important. 


\section{Chapter 1 \\ Introduction}

Agriculture is a pillar of the Nebraska economy. Nebraska's total net farm income has averaged a little over $5 \%$ of the state's total personal income and about $7 \%$ of the state's gross domestic product in recent years. Those percentages rank Nebraska third highest of the 50 states and the highest of any state with a population over 1 million. These figures represent only the direct agricultural production sector and grow substantially when closely related industries are considered such as farm suppliers and merchandisers, food processing firms, agriculturally related manufacturing firms, and transportation companies that haul agricultural inputs and products. These industries are collocated due to the abundance of agricultural crop and livestock production in Nebraska. Together, these agriculture production and agricultural-related entities create a multi-faceted agricultural production complex that accounts for a substantial share of Nebraska's economic activity and output.

This agricultural production complex is an important part of Nebraska's economic history, dictating many of the early settlement patterns still observed throughout the state today. But the complex will also be a very important part of Nebraska's economic future. This is because the state's production agriculture and its related manufacturing, wholesale, and transportation industries are leaders in an intensely competitive international food industry. To thrive in that industry, this state's agricultural producers and manufacturers have been innovative, being early adopters of cutting-edge technologies and management techniques. These features allow the complex to be a leader in international trade and create a solid foundation for the Nebraska economy. Data from the Nebraska Rural Poll, an annual survey of Nebraskans outside the Omaha and Lincoln metropolitan areas, confirms widespread acknowledgement of this impact. More than three-fourths (78\%) of rural Nebraskans responding to the poll in 2017 viewed their economic well-being as dependent on agriculture. This was never clearer than during the "Great Recession," when the export strength of Nebraska agriculture helped the state stave off the worst effects of that recession or during the COVID-19 pandemic when Nebraska's economy fared stronger than most during the initial economic slowdown due in part to the strength and output of the essential agricultural sector. 
Thinking long-term, the Nebraska agriculture production complex will likely continue to grow, exporting more with the ongoing development of the global middle classes in China, India, and other countries of Asia and in Latin America. In many instances, that growth will help preserve employment and family-based agricultural operations. But, employment and income also will grow in other industries of the agricultural production complex such as food processing, agricultural manufacturers and biotechnology companies, and in the transportation entities that carry agricultural inputs and products between stages of production and on to international markets.

Given the importance and diversity of Nebraska's agricultural production, an upto-date study estimating the economic impact of the Nebraska agricultural production complex was deemed necessary. The most recent studies were done with available data for 2010 and for 2002 (Thompson, et al., 2012 and Lamphear, 2006) while there are historical analyses as well (Taylor, et al., 1994 and Lamphear and Turner, 1979). For this study, 2017 was chosen as the benchmark year of analysis. While the year 2017 was the lowest net farm income year for Nebraska agriculture since 2006, it was also a Census of Agriculture year. Leveraging the census data results provides a more accurate analysis of the economic impact of the complex across the state.

The study focuses on the statewide economic impact of agriculture in Nebraska. However, sub-state results also are presented for eight Nebraska regions (which correspond directly to the sub-state Agricultural Statistics Districts as used by the National Agricultural Statistics Service of USDA). This sub-state analysis indicates the significance of the economic impact within different regions of Nebraska. As would be expected, the agricultural production complex is a critical part of the economy throughout the state; but is the dominant industry in several non-metropolitan regions of Nebraska.

This study is a joint collaborative effort of the University of Nebraska-Lincoln (UNL) Department of Agricultural Economics and the Bureau of Business Research within the UNL Department of Economics and is funded internally by the Institute of Agricultural and Natural Resources (IANR) at UNL. It draws on substantial expertise in key issues affecting agriculture such as irrigation, natural resources, the agricultural equipment industry, and community economic development. 
This report is organized into six chapters. Following this introduction, the second chapter provides a description of the agricultural production complex in Nebraska. Chapter 3 describes the economic impact methodology utilized in the study. The statewide economic impact of the agricultural production complex is presented in the Chapter 4 while Chapter 5 presents the economic impact of agriculture within the eight sub-state regions. Conclusions and implications are presented in Chapter 6. 


\section{Chapter 2 \\ Industry Statistics within the Agricultural Production Complex}

The agricultural production complex in Nebraska is a large and diverse set of sectors involved in raising and processing crops and livestock, along with agriculturerelated activities in the manufacturing, wholesale, transportation, and tourism sectors. This Chapter describes characteristics of the complex including basic information such as industry output in each of its segments. Data on farm and ranch activity in Nebraska primarily comes from the 2017 Census of Agriculture (National Agricultural Statistics Service) while information about output in agricultural-related manufacturing, wholesale, transportation and tourism activity comes from the IMPLAN (IMpact analysis for PLANing) model. IMPLAN is an input-output analysis software package and database which provides a detailed picture of the economy in each state and county in the United States. IMPLAN data for 2017 is utilized.

\section{A. Agricultural Production Complex}

The agricultural production complex includes a set of entities closely involved in the growing and processing of food products. The complex is therefore much broader than farms and ranches, including closely related industries such as food processors, farm suppliers and merchandisers, farm equipment manufacturers, trucking and rail services, and wholesalers. Nebraska also has a small but growing agri-tourism industry.

To understand the agricultural production complex, it is important to consider the linkages that include crop and livestock production. Figure 2.1 shows both "backward" and "forward" linked industries in crop production for the example of corn production. Backward linked industries are suppliers to crop production such as farm machinery, production inputs, and transportation services that haul crops to market or supplies and equipment to farms. Forward linked industries are the customers of crop production and are often highly dependent on local supplies in order to be viable businesses. A large supply of local grain is the basis of grain processing businesses such as grain elevators and ethanol plants. 
There are also forward linkages to a variety of livestock feeding operations such as beef cattle, swine, and dairy cattle. Figure 2.2 shows selected backward and forward linkages for livestock operations for the example of beef cattle. Livestock producers utilize pharmaceutical products and feed grains. Forward linked industries include meat processors and wholesalers.

\section{Figure 2.1 Backward and Forward Linked Industries for Corn Production Backward Linkages $\quad$ Forward Linkages Production Inputs $\longrightarrow$ Grain Elevators \& (seed, fertilizer, pesticides, etc.)

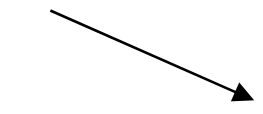 \\ Farm Machinery

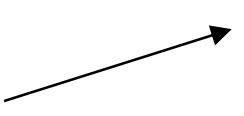 \\ Corn

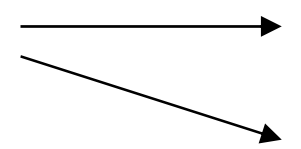 \\ Wholesalers

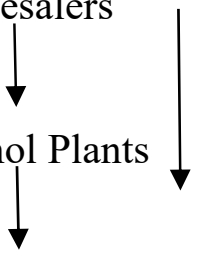 \\ Livestock Feeding}

\section{Figure 2.2 Backward and Forward Linked Industries for Beef Cattle Production}

Backward Linkages

Feed Grains

Pharmaceutical

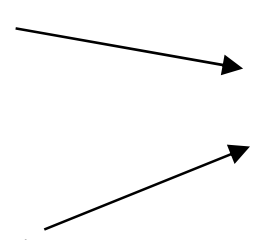
(1) 
economic activity that occur on Nebraska farms and ranches, such as agri-tourism. In addition, the complex includes other industries that service or process crops and livestock, and are collocated in Nebraska because of the abundant production of corn, soybeans, and other crops as well as cattle, hogs, and other livestock. The components of the agricultural production complex are:

${ }^{\circ}$ Crop production (Irrigated and Nonirrigated)

${ }^{\circ}$ Livestock Production

○ Agricultural-Related Manufacturing (Durable and Non-durable)

- Agricultural-Related Wholesaling and Transportation

○ Agri-Tourism

This definition includes many important agricultural service industries, but also excludes several relevant support activities for agriculture including finance, veterinary services, and consultant services, among others. It would be appropriate to include these agricultural services providers within the agricultural production complex in the analysis that follows; however, doing so is beyond the scope of the current report. Fortunately, economic activity in these industries will be captured as part of the economic multiplier of the agricultural production complex.

\section{B. Description of the Complex}

The first component is the total production of crops in Nebraska. In Table 2.1, output estimates are provided for the state's major crop categories as well as other important crops. The covered crops are corn, soybeans, wheat, grain sorghum, alfalfa hay and other hay as well as sugar beets, dry beans, sunflowers, dry peas, proso millet, oats, and barley. Separate sales information is provided for irrigated and nonirrigated acres for corn and soybeans. Data on harvested acres of 2017 production and prices are primarily from the 2017 Census of Agriculture.

Data from the 2017 Census of Agriculture indicates that 19.0 million acres of these major crops were harvested in Nebraska in 2017. Total values of the selected crops were $\$ 9.31$ billion. Three-fifths $(60 \%)$ of the dollar value was corn, from both irrigated and nonirrigated acres. Soybean sales accounted for another $31 \%$ of all crop proceeds in 
2017. The remaining $9 \%$ of sales were divided among wheat, alfalfa hay, and other hay, as well as sugar beets, dry beans, oats, grain sorghum, sunflowers, dry peas, proso millet, oats, and barley. Not all crop production is included; specifically, \$149 million in fruit, vegetable and horticultural production is not included in the analysis.

\section{Table 2.1: Nebraska 2017 Crop Production for Selected Crops}

\begin{tabular}{lccccc}
\hline Industry & $\begin{array}{c}\text { Harvested } \\
\text { Crop Acres }\end{array}$ & Yield/Acre & $\begin{array}{c}\text { Production } \\
(1000 \mathrm{~s})\end{array}$ & $\begin{array}{c}\text { Price per } \\
\text { Unit }\end{array}$ & $\begin{array}{c}\text { Total Value } \\
\text { (Millions \$) }\end{array}$ \\
\hline \hline Irrigated Corn & & & & & \\
Nonirrigated Corn & $5,077,724$ & $209 \mathrm{bu}$. & $1,061,435$ & $\$ 3.31$ & $\$ 3,512$ \\
Irrigated Soybeans & $4,377,307$ & $145 \mathrm{bu}$. & 633,464 & $\$ 3.30$ & $\$ 2,091$ \\
Nonirrigated Soybeans & $2,509,026$ & $64 \mathrm{bu}$. & 160,838 & $\$ 9.00$ & $\$ 1,448$ \\
Wheat & $3,155,199$ & $49 \mathrm{bu}$. & 155,438 & $\$ 8.98$ & $\$ 1,396$ \\
Grain Sorghum & $1,060,786$ & $44 \mathrm{bu}$. & 47,165 & $\$ 3.58$ & $\$ 169$ \\
Sunflowers & 116,266 & $82 \mathrm{bu}$. & 9,545 & $\$ 4.54$ & $\$ 43$ \\
Dry Peas & 41,438 & $1.3 \mathrm{cwt}$. & 53 & $\$ 20.40$ & $\$ 11$ \\
Proso Millet & 56,813 & $1.4 \mathrm{cwt}$. & 821 & $\$ 12.10$ & $\$ 10$ \\
Oats & 86,355 & $32 \mathrm{bu}$. & 2,774 & $\$ 3.13$ & $\$ 9$ \\
Barley & 34,136 & $55 \mathrm{bu}$. & 1,884 & $\$ 2.62$ & $\$ 5$ \\
Sugar Beets & 2,518 & $39 \mathrm{bu}$. & 98 & $\$ 5.86$ & $\$ 1$ \\
Dry Edible Beans & 47,418 & $30 \mathrm{tn}$. & 1,407 & $\$ 33.70$ & $\$ 47$ \\
Alfalfa Hay & 153,926 & $25 \mathrm{cwt}$. & 3,865 & $\$ 25.50$ & $\$ 99$ \\
Other Hay & 958,720 & $3.4 \mathrm{tn}$. & 3,300 & $\$ 97.00$ & $\$ 320$ \\
\hline Total & $1,324,731$ & $1.5 \mathrm{tn}$. & 2,006 & $\$ 77.00$ & $\$ 154$ \\
\hline Sat & $19,000,363$ & & & & $\$ 9,314$ \\
\hline
\end{tabular}

Source: USDA-NASS/2017 Census of Agriculture.

Table 2.2 shows the total estimated production value for livestock in Nebraska in 2017. Estimates are provided for the four major livestock groupings including cattle production (including dairy cattle), hog production, milk production, and poultry and egg production, as well as for horses (and other equine), sheep and goats. The total sales were $\$ 12.64$ billion in 2017. Approximately $84 \%$ of total livestock sales were in cattle production. Hog production was the next largest category, accounting for nearly $12 \%$ of total sales. As with crops, not all livestock production is included; specifically, $\$ 31$ million dollars of other livestock production is not included in the analysis. 


\begin{tabular}{lc}
\hline Table 2.2: Nebraska 2017 Livestock Production \\
\hline & $\begin{array}{c}\text { Total Value } \\
\text { (Millions \$) }\end{array}$ \\
\hline Industry & $\$ 10,642$ \\
Cattle Production (Beef and Dairy) & $\$ 288$ \\
Milk Production & $\$ 194$ \\
Poultry and Egg Production & $\$ 1,489$ \\
Hog Production & $\$ 12$ \\
Sheep and Goats (Wool, Mohair \& Milk) & $\$ 16$ \\
Equine & $\$ 12,641$ \\
\hline Total &
\end{tabular}

Table 2.3 shows the sales of agriculture-related manufacturing industries in Nebraska. Data on industry sales were gathered primarily from the IMPLAN model. There are three primary types of agriculture-related manufacturing industries: food processing, ethanol production, and machinery, structures, and pharmaceuticals. The total sales of agriculture-related manufacturing industries were $\$ 32.63$ billion in 2017 , approximately $50 \%$ more than the combined production value of crops and livestock at the farm/ranch level.

Animal slaughtering (except poultry) was the largest industry, accounting for $43 \%$ of all sales of agriculture-related manufacturing industries. This corresponds to the fact that Nebraska ranks $1^{\text {st }}$ among the 50 states in commercial red meat production. Four other food processing industries had over $\$ 1$ billion in sales during 2017, including dog and cat food manufacturing, other animal food manufacturing, meat rendered from carcasses, and soybean and other oilseed processing. Ethanol sales were approximately $\$ 3.76$ billion in 2017 . There also were substantial sales in machinery, structures and pharmaceuticals for agriculture. Farm machinery and equipment sales were $\$ 2.16$ billion in 2017. The sales of botanical, pharmaceutical, and biological products were $\$ 1.49$ billion. 


\begin{tabular}{lc}
\hline $\begin{array}{l}\text { Table 2.3: 2017 Nebraska Sales in Agriculture-Related Manufacturing } \\
\text { Industries }\end{array}$ & \\
\hline Industry & Sales (Millions \$) \\
\hline \hline & \\
Food Processing & $\$ 14,544$ \\
Animal Slaughtering (except Poultry) & $\$ 2,623$ \\
Meat Rendered from Carcasses & $\$ 180$ \\
Rendering and Meat Byproduct Manufacturing & $\$ 226$ \\
Animal Slaughtering (Poultry) & $\$ 1,886$ \\
Dog and Cat Food Manufacturing & $\$ 1,478$ \\
Other Animal Food Manufacturing & $\$ 464$ \\
Flour Milling and Malt Manufacturing & $\$ 32$ \\
Malt Manufacturing & $\$ 1,286$ \\
Soybean and Other Oilseed Processing & $\$ 173$ \\
Fats and Oils Refining and Blending & $\$ 689$ \\
Breakfast Cereal Manufacturing & $\$ 157$ \\
Sugar Beet Manufacturing & $\$ 67$ \\
Dry, Condensed and Evaporated Dairy Manufacturing & $\$ 282$ \\
Fluid Milk Manufacturing & $\$ 231$ \\
Butter Manufacturing & $\$ 25$ \\
Cheese Manufacturing & $\$ 726$ \\
Other Food Processing & $\$ 3,764$ \\
Ethanol Production & $\$ 152$ \\
Machinery, Structures, and Pharmaceuticals & $\$ 32,630$ \\
Farm Machinery \& Equipment & \\
Fabricated Metal Buildings & \\
Botanical, Pharmaceutical, and Biological Products & \\
\hline Total & \\
Source: IMPLAN and Economic Impacts of the Nebraska Ethanol and Ethanol Co-Products Industry 2015-2017. \\
\end{tabular}

Table 2.4 shows the sales of agriculture-related wholesale and transportation industries. The table shows the total sales of farm suppliers and merchandisers, farm machinery wholesalers, and an estimate of state trucking and rail services supported by Nebraska agriculture. Data on sales for both wholesale industries were gathered from the 2017 Economic Census. Data on wholesale sales are adjusted to account for only the "mark-up" portion of sales, excluding the cost of goods sold. The mark-up portion is what supports employment and operating activity within the state's wholesale sector. Focusing on the mark-up also avoids double-counting the value of agricultural products produced in Nebraska. The share of industry activity which is due to a mark-up is 
estimated using the IMPLAN model. Trucking and rail services are estimated using IMPLAN, which provides an estimate of the share of trucking and rail services purchased from in-state providers by crop producers, livestock producers, food processing businesses, and farm suppliers, and merchandisers. Nebraska agriculture-related trucking activity, at \$2.12 billion, accounted for 40\%of all Nebraska trucking activity in 2017 . Nebraska agriculture-related rail activity accounted for $5 \%$ of Nebraska rail activity in 2017. The total adjusted sales of agriculture-related wholesaling and transportation activity was $\$ 4.20$ billion.

\begin{tabular}{lc}
\hline $\begin{array}{l}\text { Table 2.4: 2017 Sales of Agriculture-Related Wholesaling and } \\
\text { Transportation Activity }\end{array}$ \\
\hline Industry & Sales (Millions \$) \\
\hline \hline Farm Supply and Merchandising & $\$ 961$ \\
Truck Transportation & $\$ 2,121$ \\
Rail Transportation & $\$ 296$ \\
Equipment Dealers & $\$ 819$ \\
\hline Total & $\$ 4,197$ \\
\hline Source: IMPLAN.
\end{tabular}

Table 2.5 shows the estimated agri-tourism sales in Nebraska in 2017. Statewide sales data were derived utilizing the IMPLAN model, which provided information on the share of sales of "other amusement and recreation" services on farms and ranches. Such other recreation refers to the agri-tourism activity occurring on these farms and ranches such as leasing land for hunting, birding, or other on-farm recreation activities or hosting events such as fruit or vegetable harvesting opportunities, agricultural festivals, or themed events (such as pumpkin farms and other entertainment venues). Information on commodity sales from Table 2.1 is combined with IMPLAN data on the share of other amusement and recreation sales to yield the estimate in the Table below.

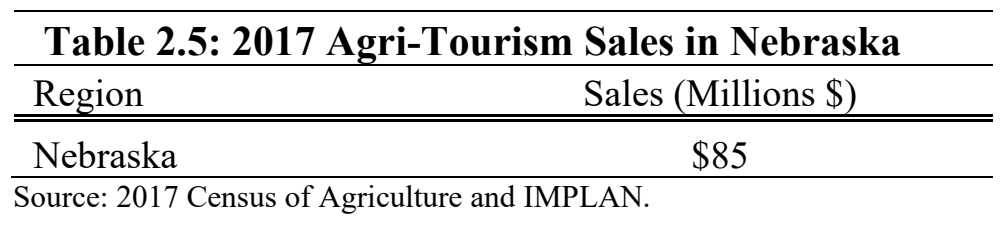




\section{Chapter 3}

\section{Method for Evaluating the Economic Impact}

This chapter discusses the methodology for calculating the total economic impact on Nebraska of the agricultural production complex, including the jobs and economic activity in the complex itself as well as the jobs and economic activity which it supports in the larger economy. Economic activity within the complex itself includes the business sales, employment, and labor income (wages and salaries, proprietor's income, and employee benefits) within crop and livestock production businesses and agriculturerelated manufacturing, wholesale, transportation, and tourism activity. Businesses in other sectors of the economy also benefit from production in the agricultural production complex, by providing goods and services to the complex, and from workers in the complex spending their paychecks in a variety of industries. These sales generate additional jobs, salaries, and other regional business activity known as multiplier impacts.

The multiplier impact refers to economic activity supported in other industries besides those in the agricultural production complex itself. This multiplier impact therefore includes purchased business supplies such as accounting services, veterinary services, legal services, or construction activities. The multiplier impact also includes businesses throughout the economy where workers in the agricultural production complex would spend their paychecks such as retail businesses, eating and drinking places, entertainment and recreation businesses, utilities, housing, health care, and insurance businesses. The multiplier impact therefore captures how business activity throughout the economy benefits from the agricultural production complex.

The total economic impact on Nebraska from the agricultural production complex is the sum of the direct impact and the multiplier impact. Figure 3.1 shows how the total economic impact is calculated for each industry within the agricultural production complex. As the figure shows, purchases by firms from businesses outside of the agricultural production complex are part of the multiplier effect. Further, purchases by employees of the complex also contribute to the multiplier impact. The multiplier impact is added to the direct impact to yield the total economic impact. 
It is important to note that a distinction is made between these outside purchases and purchases from other businesses and industries within the agricultural production complex. Those purchases from other entities within the complex are not part of the multiplier impact and do not contribute to the total economic impact. This is done to avoid double-counting, since the business receipts, employment, and labor income of these industries are already part of the direct economic impact of the agricultural production complex

\section{Figure 3.1 Approach for Calculating the Economic Impact of Industry with the Agricultural Production Complex}

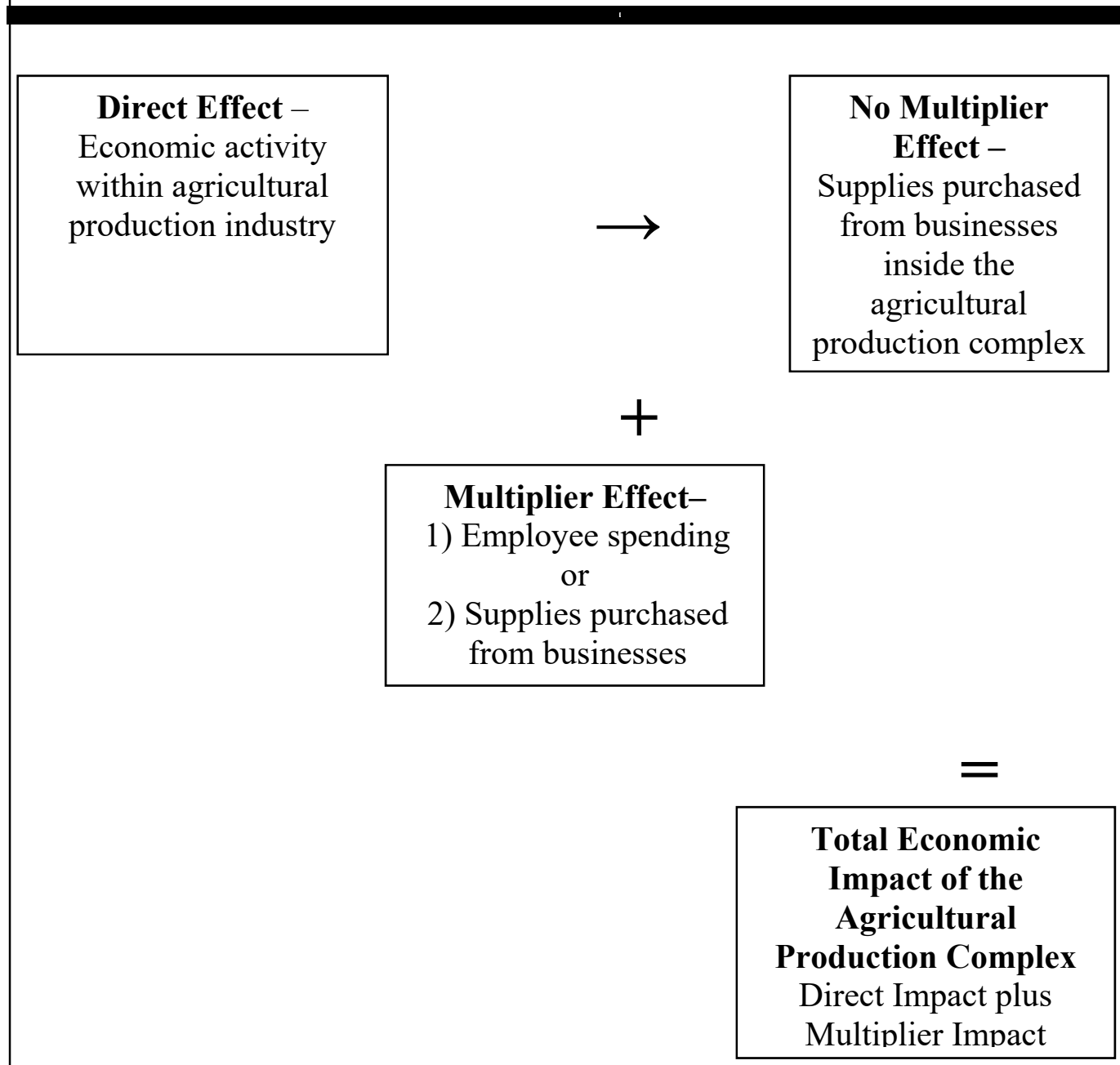

In this analysis, business receipts, contribution to gross state product, employment, and labor income are estimated for each industry within the agricultural 
production complex. ${ }^{1}$ Then, the multiplier impact is estimated for each industry, showing the additional business receipts, contribution to gross state product, employment, and labor income generated at businesses outside of the agricultural production complex. More specifically, a set of "economic multipliers" is estimated for each industry within the agricultural production complex. One economic multiplier shows the business receipts generated at businesses outside of the agricultural production complex for each $\$ 1$ of business receipts in an agricultural production complex industry. Another economic multiplier shows the jobs generated at businesses outside of the agricultural production complex for each job in a complex industry. A similar economic multiplier is calculated for labor income while there is another multiplier for the contribution to gross state product. The economic multipliers always show the additional economic activity generated outside of the agricultural production complex for $\$ 1$ (or 1 job) of economic activity in an agricultural production complex industry.

Consider a hypothetical example of an economic multiplier for business receipts from hog farming, which is one of the industries within the agricultural production complex. In the example, assume that the total business receipts (i.e., sales) of the hog farming industry were $\$ 1$ billion in 2017 and that the economic multiplier for business receipts is 0.5 . The direct economic impact measured in business receipts is $\$ 1$ billion. The multiplier impact on Nebraska businesses outside of the agricultural production complex is $\$ 0.5$ billion (i.e., 0.5 multiplied by each $\$ 1$ in business receipts in the hog farm industry). So, the total economic impact of the hog farm industry in Nebraska would be $\$ 1.5$ billion. A similar set of calculations could be made for the total employment impact, labor income impact, or gross state product impact of the hog farming industry. All that is required is information on the direct economic activity in hog farming (whether business receipts, contribution to gross state product, employment, or labor income) and the appropriate economic multiplier.

Appropriate economic multipliers must be calculated for each specific industry. This is because the value of the economic multipliers can vary, sometimes substantially, across specific industries within the agricultural production complex. For example, crop

\footnotetext{
${ }^{1}$ Formally, the IMPLAN model provides estimates of contributions to value-added but these are the same as contributions to gross state product
} 
production will have different economic multipliers than agriculture-related manufacturing or the trucking industry.

Unique economic multiplier impacts are calculated for each industry in this study using the 2017 IMPLAN software. This software can generate economic impact estimates for hundreds of individual industries in every U.S. county or state, or combinations of counties and states.

In this report, a set of four economic multipliers (business receipts, gross state product, labor income, employment) were generated for the State of Nebraska in each specific industry within the agricultural production complex. Additionally, another set of multipliers were calculated for each specific industry within the complex for each of the eight sub-state regions of Nebraska. Multiplier values for the eight regions are typically less than the statewide multipliers, since some suppliers are located within a different region of Nebraska. The sum of regional economic impacts, therefore, will not add to the statewide impact.

Economic multipliers were then applied to the industry data presented in Chapter 2 in order to calculate the total economic impact of the agricultural production complex in Nebraska. Statewide economic impacts are presented in Chapter 4. Economic impacts for each sub-state region are presented in Chapter 5. 


\section{Chapter 4}

\section{Statewide Economic Impact}

The large and diverse agricultural production complex in Nebraska includes a variety of inter-related industries such as crop production, livestock, food processing, transportation, and wholesale services, as was noted in the previous chapter. This chapter considers the total economic impact of the complex, providing an estimate of the economic impact of the complex itself, and the additional business and employment opportunities it supports throughout the Nebraska economy. The analysis is calculated for each component of the agricultural production complex. Results are then summarized for the complex overall, and the impact of the complex is compared with the aggregate Nebraska economy.

\section{A. Statewide Economic Impact of Crop Production in Nebraska}

As noted in Chapter 3, the estimated value of crop production among the covered crops of corn, soybeans, wheat, grain sorghum, oats, sugar beets, dry beans, alfalfa hay, other hay, and other crops was $\$ 9.31$ billion in 2017 . This figure, with one adjustment, represents the direct economic impact of the crop sector on the Nebraska economy. The required adjustment is for seed purchases. Part of the sales for corn, soybeans, and many of the other crops is to produce seeds used to grow these crops in Nebraska. Total Nebraska value of production for each crop must be adjusted to account for estimated seed purchases within Nebraska, as is done in Table 4.1A below. This adjustment is naturally minimal for the case of alfalfa and other hay.

Table 4.1A also shows the economic impact calculation for each of the crops. This includes the direct impact and the multiplier impact. As has been noted, the multiplier impact includes impacts on businesses outside of the agricultural production complex, and therefore, does not include economic impacts on farm suppliers and merchandisers or transportation businesses. The total economic impact is the direct impact plus the multiplier impact.

Results from Table 4.1A show that irrigated crop production accounts for more than half of the total economic impact of the crop sector. Irrigated corn ( $\$ 5.23$ billion) and irrigated soybeans ( $\$ 2.35$ billion) together account for $\$ 7.58$ billion of a $\$ 14.43$ 
billion crop impact, or $53 \%$ of the total. The share would grow further if irrigated sugar beets, alfalfa hay, other hay, wheat, or other types of production were included.

\begin{tabular}{lcccc}
\hline $\begin{array}{l}\text { Table 4.1A 2017 } \\
\text { Industries }\end{array}$ & Economic Impact & (Business Receipts) of Crop Production \\
\hline Industry & $\begin{array}{c}\text { Total Value } \\
\text { (Millions } \$ \text { ) }\end{array}$ & $\begin{array}{c}\text { Direct Impact } \\
\text { (Millions } \$ \text { ) }\end{array}$ & $\begin{array}{c}\text { Multiplier } \\
\text { (Millions } \$ \text { ) }\end{array}$ & $\begin{array}{c}\text { Total } \\
\text { (Millions \$) }\end{array}$ \\
\hline \hline Irrigated Corn & $\$ 3,512$ & $\$ 3,203$ & $\$ 2,030$ & $\$ 5,233$ \\
Nonirrigated Corn & $\$ 2,091$ & $\$ 1,920$ & $\$ 1,191$ & $\$ 3,111$ \\
Irrigated Soybeans & $\$ 1,448$ & $\$ 1,418$ & $\$ 934$ & $\$ 2,352$ \\
Nonirrigated Soybeans & $\$ 1,396$ & $\$ 1,362$ & $\$ 958$ & $\$ 2,321$ \\
Wheat & $\$ 169$ & $\$ 160$ & $\$ 67$ & $\$ 227$ \\
Grain Sorghum & $\$ 43$ & $\$ 43$ & $\$ 27$ & $\$ 69$ \\
Sunflowers & $\$ 11$ & $\$ 11$ & $\$ 5$ & $\$ 15$ \\
Dry Peas & $\$ 10$ & $\$ 9$ & $\$ 6$ & $\$ 15$ \\
Proso Millet & $\$ 9$ & $\$ 8$ & $\$ 3$ & $\$ 12$ \\
Oats & $\$ 5$ & $\$ 5$ & $\$ 2$ & $\$ 6$ \\
Barley & $\$ 1$ & $\$ 1$ & $\$ 0$ & $\$ 1$ \\
Sugar Beets & $\$ 47$ & $\$ 43$ & $\$ 25$ & $\$ 68$ \\
Dry Beans & $\$ 99$ & $\$ 92$ & $\$ 73$ & $\$ 165$ \\
Alfalfa & $\$ 320$ & $\$ 320$ & $\$ 249$ & $\$ 569$ \\
Other Hay & $\$ 154$ & $\$ 154$ & $\$ 116$ & $\$ 271$ \\
\hline Total & $\$ 9,314$ & $\$ 8,747$ & $\$ 5,687$ & $\$ 14,434$ \\
\hline Sol &
\end{tabular}

Source: USDA-NASS (for sales) and authors' calculations using IMPLAN.

Note: Direct and Indirect values may not sum to total due to rounding.

Nonirrigated corn and soybean production also had a significant economic impact. The total economic impact of nonirrigated corn production was $\$ 3.11$ billion, the second largest among any sector. The total impact of nonirrigated soybean production was $\$ 2.32$ billion. Among remaining crops, alfalfa hay had the $5^{\text {th }}$ largest economic impact at \$569 million followed by \$271 million for other hay production and \$227 million for wheat production.

The multiplier impact was $61 \%$ as large as the direct impact. This implies that each $\$ 1$ of crop production value would yield $\$ 0.61$ in additional receipts for Nebraska businesses outside of the agricultural production complex.

Table 4.1B shows the contribution of crop production to gross state product (value-added) in Nebraska. This measure is of interest since it is akin to gross domestic product, the official measure for the size of the U.S. economy. Recall that the IMPLAN 
model can calculate the direct gross state product within an industry based on industry sales. Thus, the direct economic impact in Table 4.1B is the gross state product within crop production industries while the multiplier impact shows the impact on gross state product of Nebraska industries outside of the agricultural production complex. The total GSP impact is the direct impact plus the multiplier impact. For the crop sector as a whole, the GSP multiplier impact was $212 \%$ as large as the direct impact, meaning that each $\$ 1.00$ of GSP generated by the sector results in an addition of $\$ 2.12$ of GSP. The multiplier is so large due in part to poor profitability in agriculture during 2017.

\begin{tabular}{lccc}
\hline $\begin{array}{l}\text { Table 4.1B: 2017 } \\
\text { Industries }\end{array}$ & $\begin{array}{c}\text { Direct } \\
\text { (Millions } \$ \text { ) }\end{array}$ & $\begin{array}{c}\text { Multiplier } \\
\text { (Millions } \$ \text { ) }\end{array}$ & $\begin{array}{c}\text { Total } \\
\text { (Millions } \$ \text { ) }\end{array}$ \\
\hline Industry & $\$ 278$ & $\$ 1,060$ & $\$ 1,338$ \\
\hline Irrigated Corn & $\$ 139$ & $\$ 622$ & $\$ 762$ \\
Nonirrigated Corn & $\$ 465$ & $\$ 546$ & $\$ 1,010$ \\
Irrigated Soybeans & $\$ 438$ & $\$ 559$ & $\$ 997$ \\
Nonirrigated Soybeans & $\$ 17$ & $\$ 36$ & $\$ 53$ \\
Wheat & $\$ 3$ & $\$ 16$ & $\$ 19$ \\
Grain Sorghum & $\$ 4$ & $\$ 3$ & $\$ 6$ \\
Sunflowers & $\$ 1$ & $\$ 3$ & $\$ 4$ \\
Dry Peas & $\$ 1$ & $\$ 2$ & $\$ 3$ \\
Proso Millet & $\$ 0.4$ & $\$ 1$ & $\$ 1$ \\
Oats & $\$ 0.1$ & $\$ 0.2$ & $\$ 0.3$ \\
Barley & $\$ 10$ & $\$ 13$ & $\$ 22$ \\
Sugar Beets & $\$ 8$ & $\$ 41$ & $\$ 49$ \\
Edible Dry Beans & $\$ 71$ & $\$ 151$ & $\$ 221$ \\
Alfalfa & $\$ 33$ & $\$ 70$ & $\$ 103$ \\
Other Hay & $\$ 1,469$ & $\$ 3,121$ & $\$ 4,590$ \\
\hline Total & &
\end{tabular}

Source: Authors' calculations using IMPLAN.

Note: Direct and Indirect values may not sum to total due to rounding.

Note that the combined direct and multiplier impacts of irrigated corn and irrigated soybean production accounted for more than half (51\%) of the total GSP impact of Nebraska's crop production sector in 2017, implying a heavy reliance on irrigation for enhanced productivity.

Table 4.1C focuses on the labor income impact of crop farming. In agriculture, most of this labor income is in the form of proprietor income rather than compensation 
for wage and salary workers. Labor income is a key component of gross state product, implying that the labor income impact will be smaller than the GSP impact.

The total labor income impact of crop production in Nebraska was $\$ 2.60$ billion in 2017. Irrigated corn and soybean production continue to account for approximately half of this economic impact. Once again, the next largest impacts were in nonirrigated soybeans and corn, followed by alfalfa hay, other hay, and wheat production.

\begin{tabular}{|c|c|c|c|}
\hline \multicolumn{4}{|c|}{$\begin{array}{l}\text { Table 4.1C: } 2017 \text { Labor Income Impact of Crop Production } \\
\text { Industries }\end{array}$} \\
\hline Industry & $\begin{array}{c}\text { Direct } \\
(\text { Millions } \$) \\
\end{array}$ & $\begin{array}{l}\text { Multiplier } \\
\text { (Millions \$) }\end{array}$ & $\begin{array}{c}\text { Total } \\
(\text { Millions \$) } \\
\end{array}$ \\
\hline Irrigated Corn & $\$ 230$ & $\$ 545$ & $\$ 775$ \\
\hline Nonirrigated Corn & $\$ 110$ & $\$ 312$ & $\$ 423$ \\
\hline Irrigated Soybeans & $\$ 295$ & $\$ 283$ & $\$ 578$ \\
\hline Nonirrigated Soybeans & $\$ 275$ & $\$ 285$ & $\$ 561$ \\
\hline Wheat & $\$ 15$ & $\$ 20$ & $\$ 35$ \\
\hline Sorghum for Grain & $\$ 3$ & $\$ 8$ & $\$ 10$ \\
\hline Sunflowers & $\$ 2$ & $\$ 1$ & $\$ 4$ \\
\hline Dry Peas & $\$ 1$ & $\$ 1$ & $\$ 2$ \\
\hline Proso Millet & $\$ 1$ & $\$ 1$ & $\$ 2$ \\
\hline Oats & $\$ 0$ & $\$ 1$ & $\$ 1$ \\
\hline Barley & $\$ 0$ & $\$ 0$ & $\$ 0$ \\
\hline Sugar beets & $\$ 5$ & $\$ 7$ & $\$ 12$ \\
\hline Edible Dry Beans & $\$ 7$ & $\$ 20$ & $\$ 27$ \\
\hline Alfalfa & $\$ 40$ & $\$ 77$ & $\$ 117$ \\
\hline Hay & $\$ 18$ & $\$ 34$ & $\$ 52$ \\
\hline Total & $\$ 1,002$ & $\$ 1,596$ & $\$ 2,598$ \\
\hline
\end{tabular}

Table 4.1D shows a similar pattern for the employment impact of crop production. The direct impact reflects employment of both proprietors and hired labor on farms which are primarily engaged in crop production. The direct impact does not include unpaid farm labor. The total employment impact including the multiplier is estimated at 88,936 employment positions in 2017. 


\begin{tabular}{lccc}
\hline \multicolumn{4}{l}{ Table 4.1D 2017 Employment Impact of Crop Production Industries } \\
\hline Industry & Direct & Multiplier & Total \\
\hline \hline Irrigated Corn & 17,980 & 12,172 & 30,152 \\
Nonirrigated Corn & 12,344 & 7,210 & 19,553 \\
Irrigated Soybeans & 6,660 & 5,776 & 12,436 \\
Nonirrigated Soybeans & 7,325 & 5,976 & 13,302 \\
Wheat & 1,806 & 512 & 2,318 \\
Grain Sorghum & 101 & 155 & 256 \\
Sunflowers & 30 & 29 & 58 \\
Dry Peas & 51 & 34 & 86 \\
Proso Millet & 74 & 20 & 94 \\
Oats & 22 & 10 & 33 \\
Barley & 1 & 2 & 4 \\
Sugar Beets & 151 & 158 & 309 \\
Edible Dry Beans & 286 & 411 & 697 \\
Alfalfa & 3,704 & 1,475 & 5,179 \\
Hay & 3,825 & 634 & 4,459 \\
\hline Total & 54,362 & 34,574 & 88,936 \\
\hline Source: Authors'
\end{tabular}

Source: Authors' calculations using IMPLAN.

\section{B. Statewide Economic Impact of Livestock Production in Nebraska}

The livestock sector also has a considerable economic impact in Nebraska, with substantial production volume, as was noted in Chapter 3. Further, the industry has a broad base of economic impact. Some of that impact is within the agricultural production complex, such as the impact from livestock industry purchases of animal feed or transportation services. But much of the impact is on businesses and workers from all types of industries outside of the agricultural production complex. This section focuses on both the direct impact of the livestock industry as well as the multiplier impact that occurs outside of the agricultural production complex.

Table 4.2A shows the relationship between livestock industry sales, direct impact, and the multiplier impact. Results are shown for cattle production (including dairy cattle), hog production, milk production, and chicken and egg production, as well as for sheep and goat and equine production. These estimates, therefore, account for nearly all livestock production in Nebraska. 


\begin{tabular}{lcccc}
\hline $\begin{array}{l}\text { Table 4.2A: 2017 Economic Impact (Business } \\
\text { Industries }\end{array}$ & $\begin{array}{l}\text { Receipts) of Livestock Production } \\
\text { Total Value } \\
\text { (Millions } \$ \text { ) }\end{array}$ & $\begin{array}{c}\text { Direct } \\
\text { Impact } \\
\text { (Millions } \$)\end{array}$ & $\begin{array}{c}\text { Multiplier } \\
\text { (Millions \$) }\end{array}$ & $\begin{array}{c}\text { Total } \\
\text { (Millions \$) }\end{array}$ \\
\hline \hline & & & & \\
Industry & $\$ 10,642$ & $\$ 8,405$ & $\$ 5,963$ & $\$ 14,368$ \\
Miltle (Beef and Dairy) & $\$ 288$ & $\$ 288$ & $\$ 124$ & $\$ 412$ \\
Poultry and Eggs & $\$ 194$ & $\$ 188$ & $\$ 53$ & $\$ 241$ \\
Hogs & $\$ 1,489$ & $\$ 1,455$ & $\$ 675$ & $\$ 2,130$ \\
Sheep and Goats & $\$ 12$ & $\$ 12$ & $\$ 5$ & $\$ 17$ \\
Equine & $\$ 16$ & $\$ 15$ & $\$ 7$ & $\$ 22$ \\
\hline Total & $\$ 12,641$ & $\$ 10,363$ & $\$ 6,828$ & $\$ 17,191$ \\
\hline Source: USDA-NASS (for sales) and authors' calculations using IMPLAN. & &
\end{tabular}

Data on sales comes from the 2017 Census of Agriculture (USDA). As was true with crop production, there is a difference between the direct impact and the value of production. Feeder cattle, feeder pigs, and chickens as well as breeding stock are a significant part of livestock industry production, $=$ and are inputs purchased by cattle feeders, hog producers, and other livestock operations. For this reason, the direct impact is often significantly smaller than the total value of production, especially in the case of cattle. Overall, the total value of livestock production is $\$ 12.64$ billion but final sales for livestock are $\$ 10.36$ billion, or $92 \%$. The multiplier impact outside of the agricultural production complex was $\$ 6.83$ billion in 2017 , or $66 \%$ as large as the direct impact. In other words, each $\$ 1$ of livestock sales will yield $\$ 0.66$ in additional final sales for Nebraska businesses outside of the agricultural production complex. We note, however, that the livestock industry also has a substantial economic impact within the agricultural production complex including crop producers, food processors, wholesalers, and transportation businesses. These impacts are not included in the multiplier impact in Table 4.2A.

As expected, the cattle industry accounts for most of the total economic impact of Nebraska livestock production. Cattle production had an annual economic impact of $\$ 14.37$ billion in 2017, including a $\$ 5.96$ billion multiplier impact on businesses and workers outside of the agricultural production complex. This represents $84 \%$ of the total economic impact of livestock production in Nebraska. Hog production is the next largest 
livestock industry with a total economic impact of $\$ 2.13$ billion in 2017. Milk production had an estimated impact of $\$ 412$ million in 2017 while the poultry and egg production industry had an estimated impact of \$241 million. The economic impact from sheep and goat production and the equine sector is much less.

Table 4.2B shows the gross state product (value-added) impact of the livestock industry in Nebraska. The cattle industry continues to dominate, accounting for $79 \%$ of the total GSP impact of livestock production in Nebraska. Note also the GSP multiplier for the livestock industry. The GSP multiplier impact outside of the agricultural industrial complex is larger than the direct impact, showing the industry's strong impact on the balance of the Nebraska economy and that Nebraska farm income (a key component of direct value-added) was limited in 2017 for livestock producers. The GSP multiplier impact is $\$ 1.32$ of additional value-added for every $\$ 1.00$ of direct livestock value-added.

\begin{tabular}{lccc}
\hline $\begin{array}{l}\text { Table 4.2B: 2017 GSP (Value-added) Impact of Livestock Production } \\
\text { Industries }\end{array}$ & $\begin{array}{c}\text { Direct } \\
\text { (Millions \$) }\end{array}$ & $\begin{array}{c}\text { Multiplier } \\
\text { (Millions } \$ \text { ) }\end{array}$ & $\begin{array}{c}\text { Total } \\
\text { (Millions \$) }\end{array}$ \\
\hline Industry & $\$ 1,699$ & $\$ 2,607$ & $\$ 4,307$ \\
\hline \hline Cattle (Beef and Dairy) & $\$ 69$ & $\$ 74$ & $\$ 143$ \\
Milk & $\$ 32$ & $\$ 28$ & $\$ 59$ \\
Poultry and Eggs & $\$ 532$ & $\$ 371$ & $\$ 903$ \\
Hogs & $\$ 4$ & $\$ 3$ & $\$ 7$ \\
Sheep and Goats & $\$ 6$ & $\$ 4$ & $\$ 10$ \\
Equine & $\$ 2,342$ & $\$ 3,087$ & $\$ 5,429$ \\
\hline Total & & & \\
\hline
\end{tabular}

Source: Authors' calculations using IMPLAN.

Tables 4.2C and 4.2D show the labor market impacts of livestock production in Nebraska. The first table shows the labor income impact while the second table shows the total employment associated with that labor income. As with crop production, a large share of the direct labor income impact is proprietor income. The total labor income impact of livestock production was $\$ 3.08$ billion in 2017 , with $81 \%$ of the labor income impact attributed to cattle. Hogs had the second largest share of the labor income impact. Milk had a larger impact on labor income than poultry and eggs. Income impacts were smaller for sheep and goats and equine. Similar patterns hold for the employment impact 
of livestock production in Nebraska. The total employment impact was approximately 87,100 jobs in 2017 , with $81 \%$ of the impact due to the cattle industry. Direct employment impacts were relatively large for sheep and goats and equine, due to proprietor employment on small operations. More generally, direct employment numbers capture proprietor and hired labor in the 2017 Census of Agriculture but do not include unpaid labor.

\begin{tabular}{lccc}
\hline $\begin{array}{l}\text { Table 4.2C: 2017 Labor Income Impact of Livestock Production } \\
\text { Industries }\end{array}$ & $\begin{array}{c}\text { Direct } \\
\text { (Millions } \$ \text { ) }\end{array}$ & $\begin{array}{c}\text { Multiplier } \\
\text { (Millions \$) }\end{array}$ & $\begin{array}{c}\text { Total } \\
\text { (Millions \$) }\end{array}$ \\
\hline Industry & $\$ 1,020$ & $\$ 1,474$ & $\$ 2,494$ \\
Cattle (Beef and Dairy) & $\$ 39$ & $\$ 41$ & $\$ 80$ \\
Milk & $\$ 17$ & $\$ 16$ & $\$ 33$ \\
Poultry and Eggs & $\$ 256$ & $\$ 210$ & $\$ 466$ \\
Hogs & $\$ 2$ & $\$ 2$ & $\$ 4$ \\
Sheep and Goats & $\$ 3$ & $\$ 2$ & $\$ 5$ \\
Equine & $\$ 1,337$ & $\$ 1,745$ & $\$ 3,082$ \\
\hline Total & \multicolumn{3}{l}{}
\end{tabular}

\begin{tabular}{lccc}
\hline \multicolumn{4}{l}{ Table 4.2D: 2017 Employment of Livestock Production Industries } \\
\hline Industry & Direct & Multiplier & Total \\
\hline \hline & 36,379 & 33,855 & 70,235 \\
Cattle (Beef and Dairy) & 993 & 797 & 1,790 \\
Milk & 889 & 336 & 1,226 \\
Poultry and Eggs & 4,363 & 4,469 & 8,833 \\
Hogs & 1,354 & 36 & 1,390 \\
Sheep and Goats & 3,620 & 47 & 3,667 \\
Equine & 47,599 & 39,542 & 87,141 \\
\hline Total & \multicolumn{3}{l}{}
\end{tabular}




\section{Statewide Economic Impact of Agriculture-Related Manufacturing in Nebraska}

Agriculture-related manufacturing includes food processing firms as well as agricultural input manufacturers that serve national and international markets such as implement manufacturers, agricultural building manufacturers, and biological, pharmaceutical, and botanic products firms. These manufacturing firms are a central component of the agricultural production complex in Nebraska. These manufacturers have collocated with Nebraska's large and productive crop and livestock production sector either as a processor of those abundant agricultural products, or as a key supplier that historically served the large farm industry of the Plains and Midwest.

The total value of production and direct impact of the agriculture-related manufacturing industry is listed in Table 4.3A. This distinction is necessary because some firms in these manufacturing industries buy supplies from firms within the same industry. Total value of production of the industries was $\$ 33.63$ billion in 2017 while direct impact was $\$ 33.16$ billion.

The total economic impact of the agriculture-related manufacturing industry was $\$ 42.79$ billion in 2017 , larger than the economic impact of the crop and livestock production sectors combined. As part of that total, agriculture-related manufacturers delivered a $\$ 10.63$ billion multiplier impact. Animal slaughtering was by far the largest industry among agriculture-related manufacturers, generating an $\$ 18.87$ billion impact in 2017, or 44\% of the overall impact. Ethanol production, meat processed from carcasses, and farm machinery and equipment were the other key industries. Ethanol plants had a $\$ 4.12$ billion impact on the Nebraska economy in 2017 while meat processed from carcasses had a $\$ 3.69$ billion impact and farm machinery and equipment manufacturers had a $\$ 3.10$ billion impact. Dog and cat food manufacturing had a $\$ 2.47$ billion impact and botanicals, pharmaceuticals, and biological products had a $\$ 2.17$ billion impact. While some firms in this industry produce non-agricultural products, most are focused on agriculture, and furthermore, agricultural markets were key to the foundation of many of these manufacturing facilities in the state. Two other food processing industries had over a $\$ 1$ billion impact in 2017: animal food manufacturers and soybean processing facilities. The other food processing sector also had a combined economic impact of over $\$ 1$ billion. 


\begin{tabular}{|c|c|c|c|c|}
\hline Industry & $\begin{array}{l}\text { Total Value } \\
\text { (Millions \$) } \\
\end{array}$ & $\begin{array}{c}\text { Direct } \\
\text { Impact } \\
\text { (Millions \$) } \\
\end{array}$ & $\begin{array}{l}\text { Multiplier } \\
\text { (Millions \$) } \\
\end{array}$ & $\begin{array}{c}\text { Total } \\
\text { (Millions \$) } \\
\end{array}$ \\
\hline \multicolumn{5}{|l|}{ Food Processing } \\
\hline Dog and Cat Food Manufacturing & $\$ 1,886$ & $\$ 1,884$ & $\$ 582$ & $\$ 2,466$ \\
\hline Other Animal Food Manufacturing & $\$ 1,478$ & $\$ 1,473$ & $\$ 465$ & $\$ 1,938$ \\
\hline Flour Milling & $\$ 464$ & $\$ 459$ & $\$ 211$ & $\$ 670$ \\
\hline Malt Manufacturing & $\$ 32$ & $\$ 32$ & $\$ 17$ & $\$ 49$ \\
\hline Soybean and Other Oilseed Processing & $\$ 1,286$ & $\$ 1,255$ & $\$ 356$ & $\$ 1,611$ \\
\hline Fats and Oils Refining and Blending & $\$ 173$ & $\$ 171$ & $\$ 43$ & $\$ 215$ \\
\hline Breakfast Cereal Manufacturing & $\$ 689$ & $\$ 689$ & $\$ 245$ & $\$ 933$ \\
\hline Beet Sugar Manufacturing & $\$ 157$ & $\$ 157$ & $\$ 66$ & $\$ 223$ \\
\hline Fluid Milk Manufacturing & $\$ 282$ & $\$ 267$ & $\$ 124$ & $\$ 391$ \\
\hline Creamery Butter Manufacturing & $\$ 231$ & $\$ 221$ & $\$ 70$ & $\$ 290$ \\
\hline $\begin{array}{l}\text { Cheese Manufacturing } \\
\text { Dry, Condensed and Evaporated Dairy }\end{array}$ & $\$ 25$ & $\$ 25$ & $\$ 7$ & $\$ 32$ \\
\hline Product Manufacturing & $\$ 67$ & $\$ 67$ & $\$ 23$ & $\$ 90$ \\
\hline Animal Slaughtering (Except Poultry) & $\$ 14,544$ & $\$ 14,287$ & $\$ 4,580$ & $\$ 18,867$ \\
\hline $\begin{array}{l}\text { Meat Processed From Carcasses } \\
\text { Rendering and Meat Byproduct }\end{array}$ & $\$ 2,623$ & $\$ 2,528$ & $\$ 1,165$ & $\$ 3,692$ \\
\hline Processing & $\$ 180$ & $\$ 174$ & $\$ 92$ & $\$ 265$ \\
\hline Poultry Processing & $\$ 226$ & $\$ 221$ & $\$ 82$ & $\$ 303$ \\
\hline All Other Food Manufacturing & $\$ 726$ & $\$ 721$ & $\$ 420$ & $\$ 1,141$ \\
\hline Ethanol Production & $\$ 3,764$ & $\$ 3,764$ & $\$ 357$ & $\$ 4,121$ \\
\hline \multicolumn{5}{|l|}{$\begin{array}{l}\text { Machinery, Structures and } \\
\text { Pharmaceuticals }\end{array}$} \\
\hline Farm Machinery \& Equipment & $\$ 2,161$ & $\$ 2,141$ & $\$ 955$ & $\$ 3,097$ \\
\hline Plate Work and Fabricated Buildings & $\$ 153$ & $\$ 152$ & $\$ 75$ & $\$ 227$ \\
\hline $\begin{array}{l}\text { Botanical, Pharmaceutical, and } \\
\text { Biological Products }\end{array}$ & $\$ 1,484$ & $\$ 1,468$ & $\$ 702$ & $\$ 2,170$ \\
\hline Total & $\$ 32,630$ & $\$ 32,155$ & $\$ 10,638$ & $\$ 42,793$ \\
\hline
\end{tabular}

Table 4.3B lists the GSP (value-added) impact for the agriculture-related manufacturing industries during 2017. GSP impacts are much smaller than the output impacts. This is because manufacturing industries use many intermediate supplies, food products, or other inputs. The GSP measure simply captures the value that is added to these intermediate products during manufacturing. As seen in Table 4.3B, the multiplier impact on GSP ( $\$ 5.35$ billion) is less than the direct GSP impact ( $\$ 5.88$ billion). One 
dollar of direct GSP would lead a \$0.91 multiplier impact. The total GSP impact is $\$ 11.23$ billion.

Note that this GSP impact of $\$ 11.23$ billion exceeds the combined $\$ 10.0$ billion GSP impact of the crop and livestock production industries. Animal slaughtering (except poultry) is the largest segment of the agriculture-related manufacturing industry. The total GSP impact of this animal slaughtering industry is $\$ 4.26$ billion, or $38 \%$ of total impact.

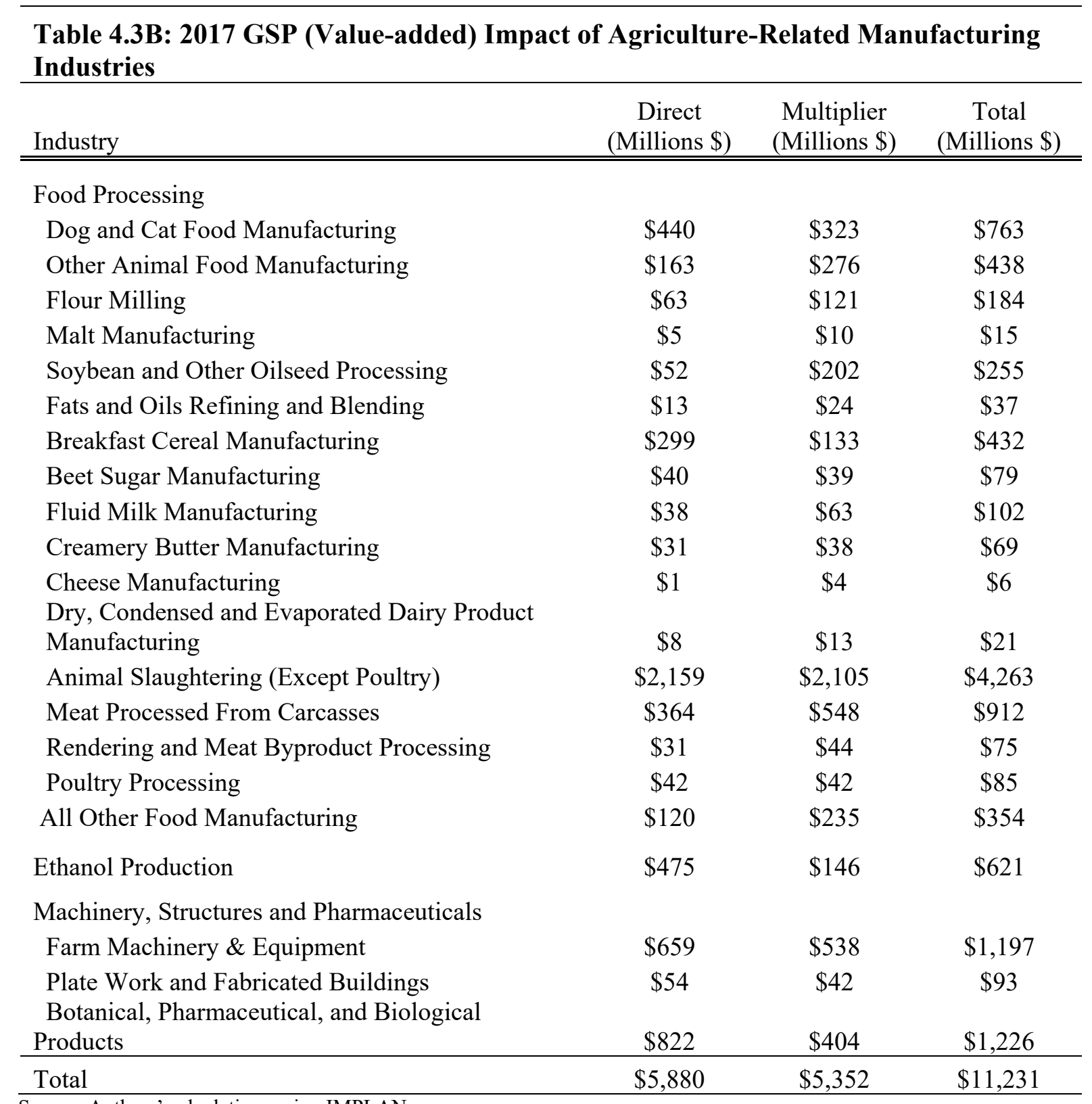

Source: Authors' calculations using IMPLAN. 
The second largest agriculture-related industry in terms of GSP impact is botanical, pharmaceutical, and biological products, with a $\$ 1.23$ billion GSP impact. Farm machinery and equipment is the third largest industry accounting for a $\$ 1.20$ billion of the GSP impact. Meat processed from carcasses is the fourth largest.

\begin{tabular}{|c|c|c|c|}
\hline Industry & $\begin{array}{c}\text { Direct } \\
\text { (Millions \$) } \\
\end{array}$ & $\begin{array}{c}\text { Multiplier } \\
\text { (Millions \$) } \\
\end{array}$ & $\begin{array}{c}\text { Total } \\
\text { (Millions \$) } \\
\end{array}$ \\
\hline \multicolumn{4}{|l|}{ Food Processing } \\
\hline Dog and Cat Food Manufacturing & $\$ 96$ & $\$ 195$ & $\$ 291$ \\
\hline Other Animal Food Manufacturing & $\$ 77$ & $\$ 158$ & $\$ 234$ \\
\hline Flour Milling & $\$ 34$ & $\$ 70$ & $\$ 104$ \\
\hline Malt Manufacturing & $\$ 2$ & $\$ 6$ & $\$ 8$ \\
\hline Soybean and Other Oilseed Processing & $\$ 19$ & $\$ 112$ & $\$ 130$ \\
\hline Fats and Oils Refining and Blending & $\$ 8$ & $\$ 14$ & $\$ 21$ \\
\hline Breakfast Cereal Manufacturing & $\$ 78$ & $\$ 80$ & $\$ 158$ \\
\hline Beet Sugar Manufacturing & $\$ 16$ & $\$ 25$ & $\$ 41$ \\
\hline Fluid Milk Manufacturing & $\$ 25$ & $\$ 37$ & $\$ 62$ \\
\hline Creamery Butter Manufacturing & $\$ 9$ & $\$ 21$ & $\$ 30$ \\
\hline Cheese Manufacturing & $\$ 1$ & $\$ 3$ & $\$ 3$ \\
\hline \multicolumn{4}{|l|}{ Dry, Condensed and Evaporated Dairy } \\
\hline Product Manufacturing & $\$ 4$ & $\$ 8$ & $\$ 12$ \\
\hline Animal Slaughtering (Except Poultry) & $\$ 1,170$ & $\$ 1,293$ & $\$ 2,462$ \\
\hline Meat Processed From Carcasses & $\$ 259$ & $\$ 338$ & $\$ 597$ \\
\hline Rendering and Meat Byproduct Processing & $\$ 28$ & $\$ 28$ & $\$ 56$ \\
\hline Poultry Processing & $\$ 36$ & $\$ 26$ & $\$ 60$ \\
\hline All Other Food Manufacturing & $\$ 89$ & $\$ 141$ & $\$ 229$ \\
\hline Ethanol Production & $\$ 109$ & $\$ 125$ & $\$ 234$ \\
\hline \multicolumn{4}{|l|}{ Machinery, Structures and Pharmaceuticals } \\
\hline Farm Machinery \& Equipment & $\$ 393$ & $\$ 321$ & $\$ 714$ \\
\hline Plate Work and Fabricated Buildings & $\$ 37$ & $\$ 22$ & $\$ 62$ \\
\hline $\begin{array}{l}\text { Botanical, Pharmaceutical, and Biological } \\
\text { Products }\end{array}$ & $\$ 153$ & $\$ 252$ & $\$ 405$ \\
\hline Total & $\$ 2,640$ & $\$ 3,276$ & $\$ 5,915$ \\
\hline
\end{tabular}

Source: Authors' calculations using IMPLAN.

Table 4.3C and Table 4.3D show the 2017 labor income and employment impact of agriculture-related manufacturing. The total labor income impact was $\$ 5.92$ billion in 2017, exceeding the combined labor income impact of the crop and livestock production. 
The total employment impact of the agriculture-related manufacturing industry in 2017 was an estimated 100,437. This is less than the combined job impact of crop and livestock production $(176,079)$, but manufacturing jobs are more likely to be full-time. The animal slaughtering (except poultry) industry accounted for $45 \%$ of employment. Farm machinery and equipment was the second largest industry followed by meat processed from carcasses and botanical, pharmaceutical and biological products.

\begin{tabular}{|c|c|c|c|}
\hline Industry & Direct & Multiplier & Total \\
\hline \multicolumn{4}{|l|}{ Food Processing } \\
\hline Dog and Cat Food Manufacturing & 1,377 & 3,356 & 4,733 \\
\hline Other Animal Food Manufacturing & 1,226 & 2,625 & 3,851 \\
\hline Flour Milling & 375 & 1,190 & 1,565 \\
\hline Malt Manufacturing & 19 & 88 & 107 \\
\hline Soybean and Other Oilseed Processing & 271 & 1,808 & 2,079 \\
\hline Fats and Oils Refining and Blending & 112 & 231 & 342 \\
\hline Breakfast Cereal Manufacturing & 712 & 1,402 & 2,114 \\
\hline Beet Sugar Manufacturing & 261 & 383 & 643 \\
\hline Fluid Milk Manufacturing & 376 & 643 & 1,019 \\
\hline Creamery Butter Manufacturing & 133 & 345 & 487 \\
\hline $\begin{array}{l}\text { Cheese Manufacturing } \\
\text { Dry, Condensed and Evaporated Dairy Product }\end{array}$ & 29 & 41 & 71 \\
\hline Manufacturing & 48 & 126 & 174 \\
\hline Animal Slaughtering (Except Poultry) & 21,121 & 24,176 & 45,297 \\
\hline Meat Processed From Carcasses & 4,968 & 6,077 & 11,045 \\
\hline Rendering and Meat Byproduct Processing & 354 & 476 & 830 \\
\hline Poultry Processing & 752 & 498 & 1,250 \\
\hline All Other Food Manufacturing & 2,056 & 2,398 & 4,454 \\
\hline Ethanol Production & 1,453 & 1,327 & 2,780 \\
\hline \multicolumn{4}{|l|}{ Machinery, Structures and Pharmaceuticals } \\
\hline Farm Machinery \& Equipment & 4,989 & 6,081 & 11,071 \\
\hline Plate Work and Fabricated Buildings & 527 & 505 & 1,032 \\
\hline Botanical, Pharmaceutical, and Biological Products & 1,395 & 4,109 & 5,504 \\
\hline Total & 42,554 & 57,882 & 100,437 \\
\hline
\end{tabular}




\section{Statewide Economic Impact of Agriculture-Related Transportation and Wholesaling in Nebraska}

Nebraska has large transportation and wholesaling sectors. This results in large part from agriculture-related activities. In particular, trucking and rail businesses haul Nebraska agricultural inputs and products around the country and also within the state. Agriculture also is related to specific segments of the wholesale industry. Specifically, farm suppliers and merchandisers and farm implement dealers are a key part of Nebraska wholesaling.

Table 4.4 lists the total economic impact of agriculture-related transportation and wholesaling, as well as the total GSP impact, and the total labor income and employment impacts. These total estimates were calculated using the same basic methodology used in the previous three sections. Summary total impact results are presented here for brevity. Detailed impacts are available in Appendix 1.

The total economic impact was $\$ 7.21$ billion in 2017 , with truck transportation accounting for the largest share of this impact, followed by farm suppliers and merchandisers. The GSP impact is $\$ 4.37$ billion, including $\$ 2.68$ billion in labor income. This labor income impact was sufficient to support 42,264 jobs.

\begin{tabular}{|c|c|c|c|c|}
\hline Industry & $\begin{array}{c}\text { Output } \\
\text { (Millions \$) } \\
\end{array}$ & $\begin{array}{c}\text { GSP } \\
\text { (Millions \$) } \\
\end{array}$ & $\begin{array}{l}\text { Labor Income } \\
\text { (Millions \$) }\end{array}$ & $\begin{array}{l}\text { Employment } \\
\text { (Millions \$) }\end{array}$ \\
\hline $\begin{array}{l}\text { Farm Supply and } \\
\text { Merchandising }\end{array}$ & $\$ 1,619$ & $\$ 1,093$ & $\$ 617$ & 8,283 \\
\hline Truck Transportation & $\$ 3,737$ & $\$ 1,969$ & $\$ 1,318$ & 24,016 \\
\hline Rail Transportation & $\$ 434$ & $\$ 304$ & $\$ 156$ & 1,574 \\
\hline Equipment Dealers & $\$ 1,421$ & $\$ 1,005$ & $\$ 591$ & 8,390 \\
\hline Total & $\$ 7,211$ & $\$ 4,371$ & $\$ 2,682$ & 42,264 \\
\hline
\end{tabular}

Source: Authors' calculations using IMPLAN.

\section{E. Statewide Economic Impact of Agri-Tourism in Nebraska}

Agricultural tourism (or agri-tourism) is an industry that some agricultural producers choose to engage in to grow or diversify their income. Agri-tourism can 
include leasing land for hunting, birding, or other on-farm recreation activities or hosting events such as fruit or vegetable harvesting opportunities, agricultural festivals, or themed events (such as pumpkin farms at Halloween and other entertainment venues).

The IMPLAN model reports the share of farm and ranch revenue that comes from providing "other recreation services," in other words, from agri-tourism. In Nebraska, the largest share of revenue from "other recreation services" occurs on grain farms, and the total annual revenue was $\$ 85$ million during 2017. Table 4.5 below shows the economic, GSP, labor income, and employment impact of such on-farm agri-tourism activity in 2017 , based on this $\$ 85$ million in revenue. Details on both the direct economic impact and the multiplier impact are provided. The total annual economic impact of agri-tourism in 2017 was $\$ 148$ million. In terms of gross state product, the total impact was $\$ 80$ million, including \$47 million in labor income. This labor income was sufficient to support an estimated 1,865 Nebraska jobs during 2017.

\begin{tabular}{lccc}
\hline $\begin{array}{l}\text { Table 4.5: 2017 Economic, GSP, Labor Income and Employment Impact } \\
\text { of Agri-Tourism }\end{array}$ & \multicolumn{3}{l}{} \\
\hline & Direct & Multiplier & Total \\
Measure & & & \\
\hline \hline & $\$ 85$ & $\$ 63$ & $\$ 148$ \\
Output (Business Receipts (\$ Millions) & $\$ 44$ & $\$ 37$ & $\$ 80$ \\
GSP (\$ Millions) & $\$ 28$ & $\$ 19$ & $\$ 47$ \\
Labor Income (\$ Millions) & 1,435 & 430 & 1,865 \\
\hline Employment
\end{tabular}

Source: Authors' calculation and IMPLAN.

\section{F. Summary of the Statewide Economic Impact of the Agricultural Production Complex}

The proceeding sections summarized the 2017 economic impact on Nebraska from crop and livestock production and the agriculture-related manufacturing, transportation, wholesale, and agri-tourism sectors. The combined annual economic impacts across all five of these industry groups is summarized below in Table 4.6. Table 4.7 compares these combined impacts from the agricultural production complex to the aggregate Nebraska economy. For internal consistency, values for statewide aggregates were taken from the IMPLAN model, even though those IMPLAN model estimates may 
differ somewhat from estimates for 2017 Nebraska GSP, labor income, or employment developed by U.S. government statistical agencies. IMPLAN estimates for crop and livestock sectors, and therefore state aggregate values, were adjusted to match values developed based on the 2017 Census of Agriculture.

The agriculture production complex was found to have a combined economic impact on output of $\$ 81.78$ billion in 2017 . Sixty-eight percent of that impact, or $\$ 55.55$ billion, was the direct output of businesses in the complex, while the remaining $32 \%$ was the multiplier impact on other Nebraska industries. As seen in Table 4.7, the total impact of $\$ 81.78$ billion is $33.9 \%$ of the total output of the Nebraska economy.

The output of the Nebraska economy includes both the value of purchased inputs (including those purchased out of state) plus the value added to those inputs by Nebraska businesses. Gross state product, by contrast, focuses on value-added. As seen in Table 4.6, the total gross state product impact of the agricultural production complex was $\$ 25.70$ billion in 2017. Forty-eight percent of that impact was due to the direct valueadded in the agricultural production complex with the remainder of the impact on other industries in Nebraska. As seen in Table 4.7, the gross state product impact of the agricultural production complex was $21.6 \%$ of total gross state product in 2017 . In short, on the basis of this metric, the complex accounts for between one-fifth and one-quarter of the Nebraska economy.

\begin{tabular}{|c|c|c|c|c|c|c|c|c|}
\hline \multirow[b]{3}{*}{ Industry } & \multirow{2}{*}{\multicolumn{2}{|c|}{$\begin{array}{c}\text { Economic Impact } \\
\text { Output } \\
\text { (Business Receipts) } \\
\text { (Millions \$) }\end{array}$}} & \multirow{2}{*}{\multicolumn{2}{|c|}{$\begin{array}{c}\text { f the Agriculture } \mathbf{P} \\
\text { Gross State Product } \\
\text { (Value-added) } \\
\text { (Millions \$) }\end{array}$}} & \multirow{2}{*}{\multicolumn{2}{|c|}{$\begin{array}{l}\text { Luction Comple } \\
\text { Labor Income } \\
\text { (Millions \$) }\end{array}$}} & \multirow{2}{*}{\multicolumn{2}{|c|}{$\begin{array}{l}\text { Nebraska } \\
\text { Employment }\end{array}$}} \\
\hline & & & & & & & & \\
\hline & Direct & Total & Direct & Total & Direct & Total & Direct & Total \\
\hline Crops & $\$ 8,747$ & $\$ 14,434$ & $\$ 1,469$ & $\$ 4,590$ & $\$ 1,002$ & $\$ 2,598$ & 54,362 & 88,936 \\
\hline Livestock & $\$ 10,363$ & $\$ 17,191$ & $\$ 2,342$ & $\$ 5,429$ & $\$ 1,337$ & $\$ 3,082$ & 47,599 & 87,141 \\
\hline $\begin{array}{l}\text { Agriculture-Related } \\
\text { Manufacturing }\end{array}$ & $\$ 32,155$ & $\$ 42,793$ & $\$ 5,880$ & $\$ 11,231$ & $\$ 2,640$ & $\$ 5,915$ & 42,544 & 100,437 \\
\hline $\begin{array}{l}\text { Transportation and } \\
\text { Wholesaling }\end{array}$ & $\$ 4,197$ & $\$ 7,212$ & $\$ 2,614$ & $\$ 4,371$ & $\$ 1,653$ & $\$ 2,683$ & 20,988 & 42,264 \\
\hline Agri-Tourism & $\$ 85$ & $\$ 148$ & $\$ 44$ & $\$ 81$ & $\$ 28$ & $\$ 47$ & 1,435 & 1,865 \\
\hline Total & $\$ 55,547$ & $\$ 81,777$ & $\$ 12,349$ & $\$ 25,701$ & $\$ 6,661$ & $\$ 14,325$ & 166,939 & 320,642 \\
\hline
\end{tabular}
Source: Authors' calculation and IMPLAN. 
Table 4.7: The Agricultural Production Complex's Share of the 2017 Nebraska Economy

\begin{tabular}{lcccc}
\hline & $\begin{array}{c}\text { Output } \\
\text { (Millions } \$ \text { ) }\end{array}$ & $\begin{array}{c}\text { Gross State Product } \\
\text { (Value-added) } \\
\text { (Millions } \$)\end{array}$ & $\begin{array}{c}\text { Labor } \\
\text { Income } \\
\text { (Millions \$) }\end{array}$ & Employment \\
\hline \hline $\begin{array}{l}\text { Impact of Agricultural Production } \\
\text { Complex }\end{array}$ & $\$ 81,777$ & $\$ 25,701$ & $\$ 14,325$ & 320,642 \\
Nebraska Total & $\$ 240,916$ & $\$ 119,182$ & $\$ 71,943$ & $1,375,294$ \\
Percentage & $33.9 \%$ & $21.6 \%$ & $19.9 \%$ & $23.3 \%$ \\
\hline
\end{tabular}

Source: Authors' calculation and IMPLAN.

Labor income is the largest component of gross state product. The labor income impact of the agriculture production complex was $\$ 14.33$ billion in 2017. Labor income includes wages, salaries, benefits, and proprietor's income. Forty-six percent of the labor income impact was income earned at businesses in the complex with the remaining income earned in other industries. The labor income impact was $19.9 \%$ of the total labor income in Nebraska. The total employment impact of the agricultural production complex was estimated to be 320,642 jobs in 2017 , or $23.3 \%$ of total Nebraska employment. The employment share exceeds the labor income share since some farm proprietor's run small operations and farm income was low overall in Nebraska during the year 2017. 


\section{Chapter 5}

\section{Sub-State Economic Impact}

Statewide analysis portrayed Nebraska's agricultural production complex as a large and diverse set of inter-related industries that account for $23.3 \%$ of the state's employment and $21.6 \%$ of its gross state product. This diversity (and economic significance) is also evident in the sub-state regional economies, and in several instances, is even more profound. The agricultural production complexes in the Northeast, South, and Southeast regions are quite diverse, showing the types of inter-related crop, livestock, agriculture-related manufacturing, transportation, and wholesaling industries that are found at the state level. Other regions are more specialized with a smaller set of collocated manufacturing industries. Western regions are more focused on livestock production, and the production of wheat, sugar beets, and dry beans.

Given this diversity, the current chapter examines the economic impact of the agricultural production complex within each of eight different sub-state regions of the Nebraska economy (Figure 5.1), utilizing the delineation of the agricultural statistics districts for the state as defined by the National Agricultural Statistics Service. The analysis focuses on production within each region, treating economic activity in other parts of the state as external. Sub-state economic multipliers are utilized rather than the state economic multipliers used in Chapter 4. This approach allows an estimate of the share of each sub-state economy accounted for by the agricultural production complex.

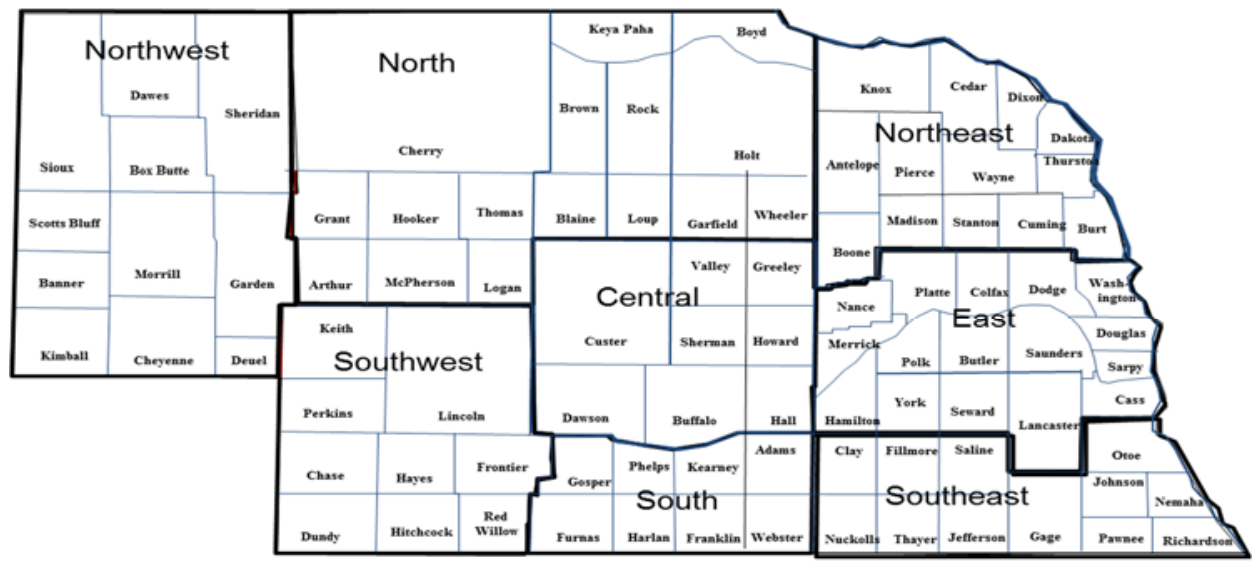

Figure 5.1 Nebraska Sub-State Economic Regions 
Table 5.1 shows the direct and total output for each of the six components of the agricultural production complex in each region. Figure 5.2 shows the economic impact of the agricultural production complex as a share of total output in each region. The total output measure includes intermediate goods purchased as well as the gross product produced within the region. ${ }^{2}$ As a result, the output measure of economic impact is a less precise measure of the economic activity that occurs within the regional economy. The gross regional product (i.e., gross state product for a region), labor income, and employment impact measures all provide a more accurate picture. Still, the output results are striking. The total economic impact of the agricultural production complex accounts for over $64 \%$ of the total output of the Northeast Nebraska region. The output share is also above $60 \%$ in the North region and above $50 \%$ in the Central, South, and Southeast regions.

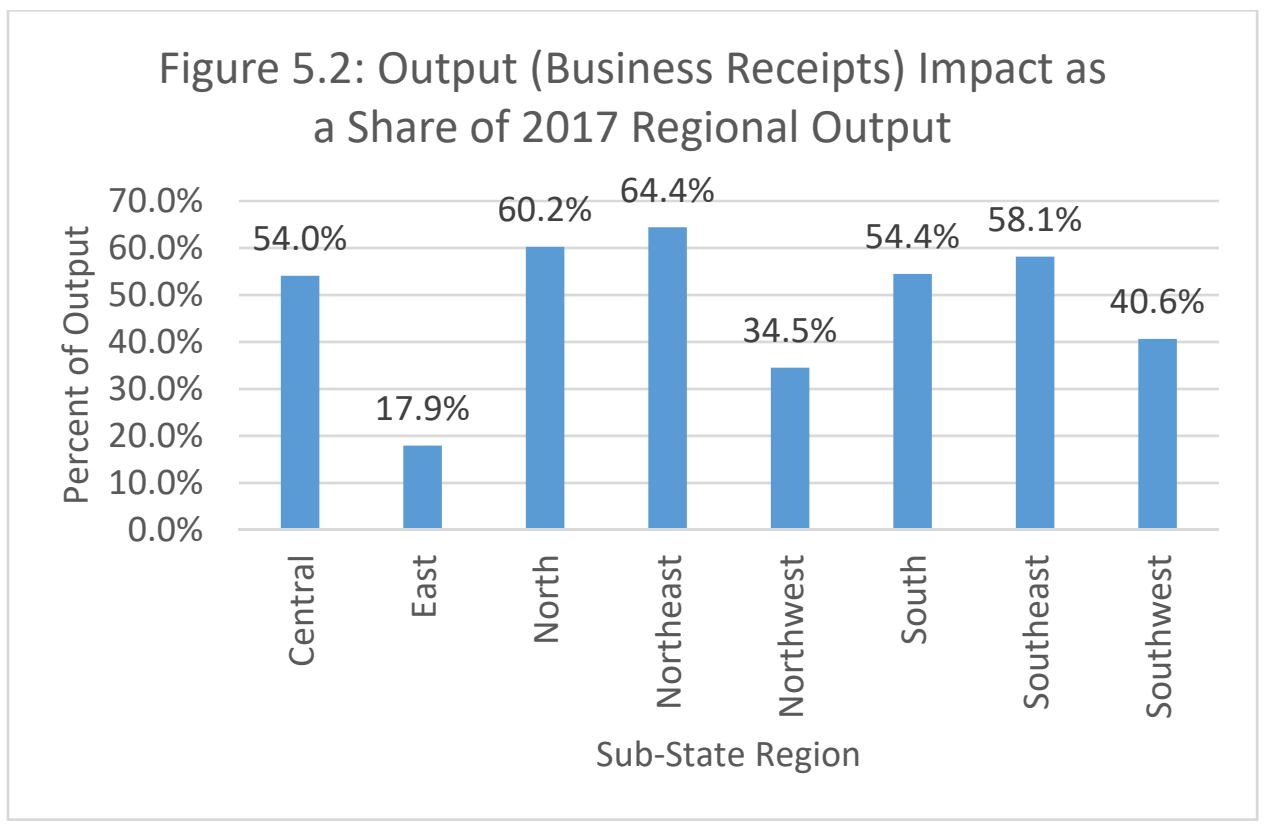

\footnotetext{
${ }^{2}$ As is true at the state level, the total output impact does not include intermediate goods purchased from other agricultural production complex businesses from in the region.
} 


\begin{tabular}{|c|c|c|c|c|c|c|c|c|c|c|c|c|c|c|c|c|}
\hline \multirow[b]{2}{*}{ Industry } & \multicolumn{2}{|c|}{ Central } & \multicolumn{2}{|c|}{ East } & \multicolumn{2}{|c|}{ North } & \multicolumn{2}{|c|}{ Northeast } & \multicolumn{2}{|c|}{ Northwest } & \multicolumn{2}{|c|}{ South } & \multicolumn{2}{|c|}{ Southeast } & \multicolumn{2}{|c|}{ Southwest } \\
\hline & Direct & Total & Direct & Total & Direct & Total & Direct & Total & Direct & Total & Direct & Total & Direct & Total & Direct & Total \\
\hline Crops & $\$ 970.5$ & $\$ 1,409.0$ & $\$ 2,092.6$ & $\$ 3,663.8$ & $\$ 432.5$ & $\$ 543.6$ & $\$ 1,676.7$ & $\$ 2,258.9$ & $\$ 517.3$ & $\$ 708.0$ & $\$ 876.1$ & $\$ 1,186.4$ & $\$ 1,419.1$ & $\$ 1,852.1$ & $\$ 762.7$ & $\$ 1,011.0$ \\
\hline Livestock & $\$ 1,587.5$ & $\$ 2,234.1$ & $\$ 1,620.7$ & $\$ 2,403.7$ & $\$ 1,107.1$ & $\$ 1,678.7$ & $\$ 2,374.0$ & $\$ 3,311.1$ & $\$ 931.8$ & $\$ 1,519.4$ & $\$ 998.3$ & $\$ 1,473.2$ & $\$ 638.7$ & $\$ 806.8$ & $\$ 1,104.9$ & $\$ 1,529.8$ \\
\hline $\begin{array}{l}\text { Agriculture- } \\
\text { Related } \\
\text { Manufacturing }\end{array}$ & $\$ 5,959.9$ & $\$ 7,148.3$ & $\$ 14,136.9$ & $\$ 18,889.2$ & $\$ 228.7$ & $\$ 257.2$ & $\$ 5,349.1$ & $\$ 6,342.4$ & $\$ 488.0$ & $\$ 604.3$ & $\$ 1,351.9$ & $\$ 1,567.3$ & $\$ 4,201.1$ & $\$ 4,721.4$ & $\$ 439.1$ & $\$ 498.7$ \\
\hline $\begin{array}{l}\text { Transportation } \\
\text { and } \\
\text { Wholesaling }\end{array}$ & $\$ 637.8$ & $\$ 985.6$ & $\$ 1,556.3$ & $\$ 2,750.3$ & $\$ 204.6$ & $\$ 273.0$ & $\$ 813.4$ & $\$ 1,138.9$ & $\$ 210.2$ & $\$ 309.4$ & $\$ 234.0$ & $\$ 327.1$ & $\$ 312.9$ & $\$ 416.5$ & $\$ 227.8$ & $\$ 326.9$ \\
\hline Agri-Tourism & $\$ 11.5$ & $\$ 17.4$ & $\$ 15.9$ & $\$ 29.3$ & $\$ 7.2$ & $\$ 9.6$ & $\$ 17.9$ & $\$ 24.9$ & $\$ 7.0$ & $\$ 9.9$ & $\$ 8.4$ & $\$ 11.5$ & $\$ 8.3$ & $\$ 10.8$ & $\$ 8.7$ & $\$ 12.1$ \\
\hline Total & $\$ 9,167.2$ & $\$ 11,794.4$ & & $\$ 27,736.3$ & & $\$ 2,762.2$ & & $\$ 13,076.2$ & & $\$ 3,150.9$ & & $\$ 4,565.5$ & & $\$ 7,807.7$ & & $\$ 3,378.5$ \\
\hline Region Total & & $\$ 21,824.9$ & & $\$ 154,929.3$ & & $\$ 4,585.4$ & & $\$ 20,313.0$ & & $\$ 9,126.7$ & & $\$ 8,385.1$ & & $\$ 13,432.3$ & & $\$ 8,319.5$ \\
\hline Percentage & & $54.0 \%$ & & $17.9 \%$ & & $60.2 \%$ & & $64.4 \%$ & & $34.5 \%$ & & $54.4 \%$ & & $58.1 \%$ & & $40.6 \%$ \\
\hline
\end{tabular}


Table 5.2 presents the economic impact estimates for major crop and livestock categories in each of the eight agricultural regions. Results show that corn and cattle are a focus of agricultural production across the eight agricultural regions. Production of other crops and livestock shows a more regional nature.

Central Nebraska exhibits a production pattern which is similar to the eastern regions of the state. South Nebraska also features a dual emphasis on corn and soybean production but has less hog production than areas to the east. Wheat production also is more common in the South region.

Another regional pattern is the concentration of soybean production and hog production in the eastern third of the state, as is evident in Northeast, East, and Southeast regions. Recent increases in poultry production in eastern Nebraska were not in place during 2017.

Western regions reflect a greater reliance on wheat and grain sorghum production but less hog production. Beef production is an even greater focus in these regions. Increased beef production is associated with a focus on raising alfalfa and hay products in the North region. The Northwest and Southwest regions exhibit even greater diversity. Nebraska's production of dry beans and sugar beets are concentrated in these two regions. More generally, Northwest Nebraska is the most diversified crop production region within the state of Nebraska. 
Table 5.2: 2017 Economic Impact of Agriculture in Nebraska -- Output (Business Receipts) by Region and by Crop and Livestock (Millions \$)

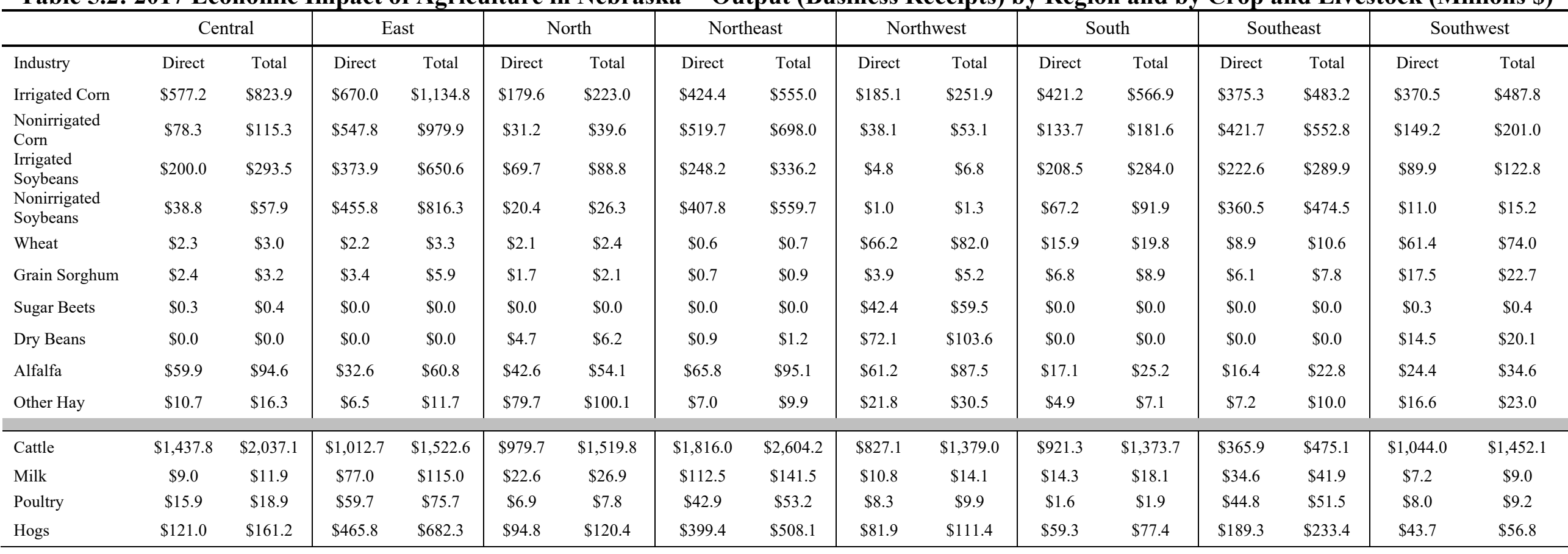




\begin{tabular}{|c|c|c|c|c|c|c|c|c|c|c|c|c|c|c|c|c|}
\hline \multirow[b]{2}{*}{ Industry } & \multicolumn{2}{|c|}{ Central } & \multicolumn{2}{|c|}{ East } & \multicolumn{2}{|c|}{ North } & \multicolumn{2}{|c|}{ Northeast } & \multicolumn{2}{|c|}{ Northwest } & \multicolumn{2}{|c|}{ South } & \multicolumn{2}{|c|}{ Southeast } & \multicolumn{2}{|c|}{ Southwest } \\
\hline & Direct & Total & Direct & Total & Direct & Total & Direct & Total & Direct & Total & Direct & Total & Direct & Total & Direct & Total \\
\hline Crops & $\$ 150.0$ & $\$ 374.9$ & $\$ 376.4$ & $\$ 1,305.5$ & $\$ 74.6$ & $\$ 123.6$ & $\$ 303.6$ & $\$ 597.5$ & $\$ 66.4$ & $\$ 157.5$ & $\$ 143.4$ & $\$ 291.3$ & $\$ 258.8$ & $\$ 460.7$ & $\$ 95.4$ & $\$ 212.3$ \\
\hline Livestock & $\$ 341.2$ & $\$ 624.5$ & $\$ 405.5$ & $\$ 840.1$ & $\$ 240.5$ & $\$ 427.9$ & $\$ 548.5$ & $\$ 923.7$ & $\$ 202.5$ & $\$ 434.1$ & $\$ 212.3$ & $\$ 391.7$ & $\$ 160.5$ & $\$ 230.3$ & $\$ 230.9$ & $\$ 402.2$ \\
\hline $\begin{array}{l}\text { Agriculture- } \\
\text { Related } \\
\text { Manufacturing }\end{array}$ & $\$ 961.4$ & $\$ 1,500.4$ & $\$ 3,073.8$ & $\$ 5,715.2$ & $\$ 25.9$ & $\$ 39.8$ & $\$ 804.3$ & $\$ 1,222.4$ & $\$ 84.1$ & $\$ 148.2$ & $\$ 154.5$ & $\$ 249.9$ & $\$ 714.1$ & $\$ 947.0$ & $\$ 61.3$ & $\$ 90.0$ \\
\hline $\begin{array}{l}\text { Transportation } \\
\text { and } \\
\text { Wholesaling }\end{array}$ & $\$ 389.6$ & $\$ 577.7$ & $\$ 946.5$ & $\$ 1,660.7$ & $\$ 136.5$ & $\$ 169.4$ & $\$ 482.9$ & $\$ 656.8$ & $\$ 140.1$ & $\$ 194.4$ & $\$ 159.7$ & $\$ 207.9$ & $\$ 204.4$ & $\$ 257.0$ & $\$ 154.7$ & $\$ 207.8$ \\
\hline Agri-Tourism & $\$ 6.0$ & $\$ 9.1$ & $\$ 8.3$ & $\$ 16.3$ & $\$ 3.7$ & $\$ 4.9$ & $\$ 9.3$ & $\$ 13.1$ & $\$ 3.6$ & $\$ 5.2$ & $\$ 4.4$ & $\$ 5.9$ & $\$ 4.3$ & $\$ 5.6$ & $\$ 4.5$ & $\$ 6.3$ \\
\hline Total & & $\$ 3,086.6$ & & $\$ 9,537.8$ & & $\$ 765.5$ & & $\$ 3,413.5$ & & $\$ 939.3$ & & $\$ 1,146.7$ & & $\$ 1,900.5$ & & $\$ 918.6$ \\
\hline Region Total & & $\$ 8,399.6$ & & $\$ 85,285.4$ & & $\$ 1,937.3$ & & $\$ 7,424.1$ & & $\$ 4,547.8$ & & $\$ 3,080.7$ & & $\$ 4,655.8$ & & $\$ 3,851.0$ \\
\hline Percentage & & $36.7 \%$ & & $11.2 \%$ & & $39.5 \%$ & & $46.0 \%$ & & $20.7 \%$ & & $37.2 \%$ & & $40.8 \%$ & & $23.9 \%$ \\
\hline
\end{tabular}


Table 5.3 shows the direct and total impact of the agricultural production complex in terms of gross regional product. Figure 5.3 shows shares of gross regional product for each region. This provides a truer measure of the share of the economy in each sub-state region that is the impact of the agricultural production complex. The largest total dollar impact is found in the East region, at $\$ 9.54$ billion in 2017 . However, as a share of the overall regional economy, the agricultural production complex accounts for just $11.2 \%$ of the gross regional product of the more metropolitan East region. While much of the impact in the East region is due to the large agriculture-related manufacturing industry, it is worth noting that the economic impact of the crop production sector is larger in the East than in any other region.

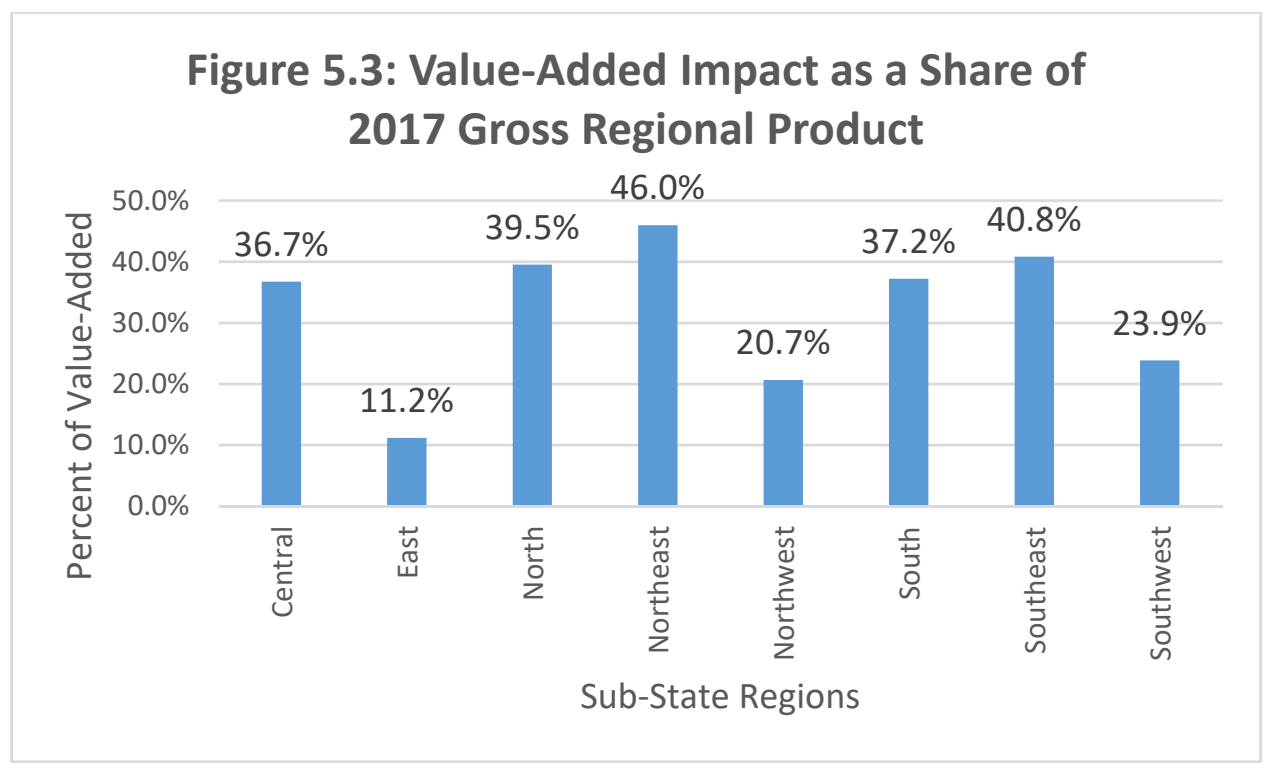

The next largest impact from the crop production sector is found in the Northeast region. The Northeast region also has the largest gross regional product impact from the livestock sector, and the third largest impact from the agriculture-related manufacturing sector. In other words, the Northeast region has the same type of large, diverse agricultural impacts that are found in the East region. Though the impact in the Northeast region is smaller than the East region in terms of absolute gross regional product, the impact is much larger in terms of share of the economy. The gross regional product 
impact of the agriculture production complex is $46.0 \%$ of the gross regional product of the Northeast region economy. In other words, nearly half of the regional economy is due to agriculture and closely related industries.

The impact from the agriculture production complex accounts for $36.7 \%$ of the economy of the Central region. Much of that impact is due to the large agriculture-related manufacturing sector, but there is also a large crop and livestock impact in the region. In terms of magnitude, the Central region has the third largest impact from the agricultural production sector, at $\$ 3.09$ billion in 2017.

The dollar value of the impact is smaller in the remaining five regions. These regions tend to have significantly smaller agriculture-related manufacturing sectors. The gross regional product impact is $\$ 1.90$ billion in the Southeast, $\$ 1.15$ billion in the South, $\$ 0.94$ billion in the Northwest, $\$ 0.92$ billion in the Southwest and $\$ 0.77$ billion in the North. However, the agricultural production complex remains a large share of the gross regional product in most of those regions. The complex accounts for $37.2 \%$ of gross regional product in the South region, $40.8 \%$ in the Southeast and 39.5\% in the North region, Overall, then, the gross regional product impact of the agricultural production complex accounts for $35 \%$ of the economy or more in five of the eight Nebraska regions. Shares are smaller in the Southwest (23.9\%) and Northwest region (20.7\%). Both of these regions have relatively little agriculture-related manufacturing activity. Apparently, the total output of crop and livestock products in these regions is not large or concentrated enough to attract a large set of collocating processors.

Similar patterns are observed for labor income, though the agricultural production complex accounts for a smaller share of labor income in most regions. Relevant data are presented in Table 5.4 and Figure 5.4. The complex accounts for more than $45 \%$ of income in the Northeast region and more than 34\% in the Central, South, Southeast and North regions. The income impact was $\$ 5.1$ billion in 2017 in the East region but this large figure accounts for just one-tenth of total income in this metropolitan region.

These broad patterns may often differ from perceptions about agriculture which are found in Nebraska. It is often surprising to metropolitan residents that the agricultural production complex accounts for such a large share of the economy, such as between one-fifth and one-quarter of the economy, as estimated in this report, while among non- 
metropolitan residents, it can be surprising that the agricultural production complex does not account for an even larger share of the regional and state economy.

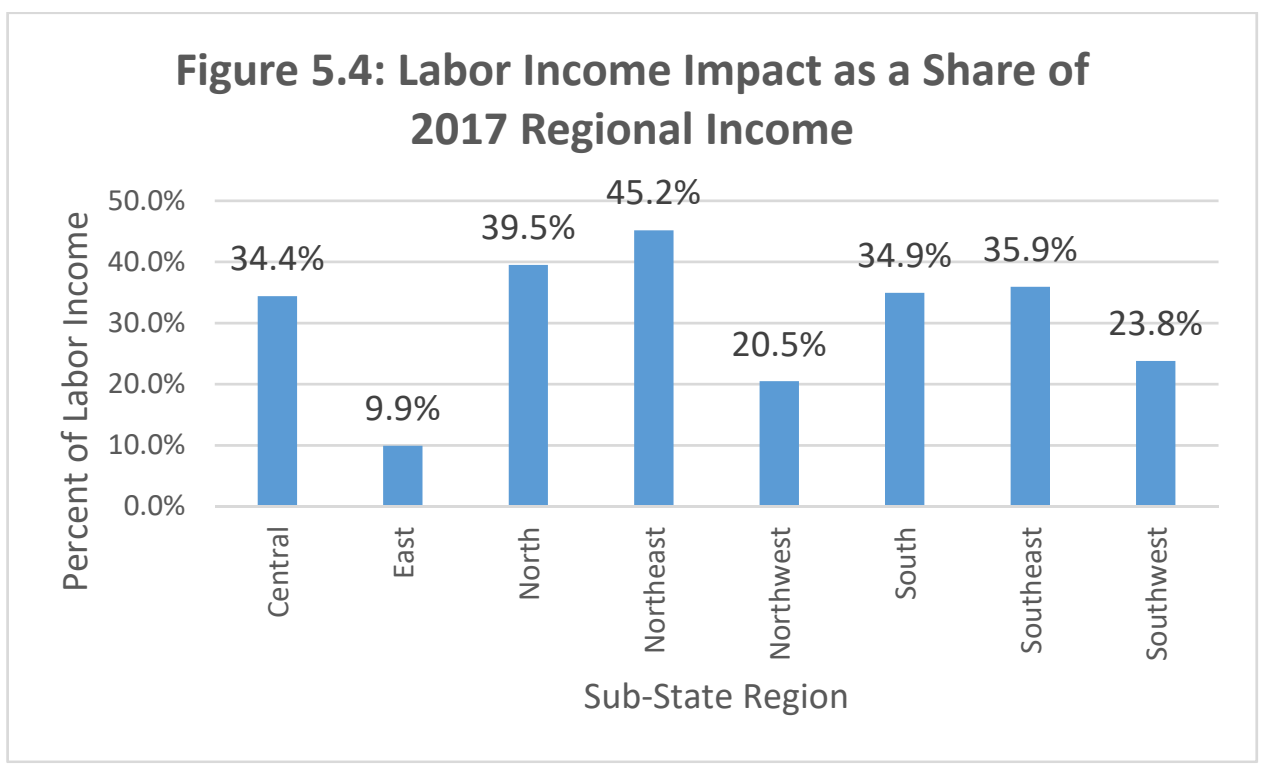

As seen in Table 5.5 and Figure 5.5, the employment impact follows the same patterns as the labor income impact, though employment impacts are generally larger as a share of the economy. This is for two reasons. First, farm proprietor incomes were relatively weak in 2017. Second, there are a large number of part-time and seasonal job opportunities on farms and ranches, implying employment counts which are large relative to labor income. The employment impact of the complex was approximately 95,900 jobs in the East region and between 43,000 to 50,000 jobs in the Central and Northeast. The impact of the complex accounted for $54.2 \%$ of employment in the North, $47.8 \%$ in the Northeast, and between 34\% and 39\% in the Central, South, Southeast, and Southwest regions. The complex accounted for just $28.3 \%$ of employment in the Northwest and just $10.7 \%$ in the East. 
Table 5.4: 2017 Economic Impact of Agriculture in Nebraska - Labor Income by Region (Millions \$)

\begin{tabular}{|c|c|c|c|c|c|c|c|c|c|c|c|c|c|c|c|c|}
\hline \multirow[b]{2}{*}{ Industry } & \multicolumn{2}{|c|}{ Central } & \multicolumn{2}{|c|}{ East } & \multicolumn{2}{|c|}{ North } & \multicolumn{2}{|c|}{ Northeast } & \multicolumn{2}{|c|}{ Northwest } & \multicolumn{2}{|c|}{ South } & \multicolumn{2}{|c|}{ Southeast } & \multicolumn{2}{|c|}{ Southwest } \\
\hline & Direct & Total & Direct & Total & Direct & Total & Direct & Total & Direct & Total & Direct & Total & Direct & Total & Direct & Total \\
\hline Crops & $\$ 104.7$ & $\$ 228.7$ & $\$ 255.0$ & $\$ 721.8$ & $\$ 48.7$ & $\$ 74.6$ & $\$ 203.9$ & $\$ 357.4$ & $\$ 46.2$ & $\$ 101.3$ & $\$ 99.6$ & $\$ 187.6$ & $\$ 174.6$ & $\$ 280.6$ & $\$ 69.8$ & $\$ 132.2$ \\
\hline Livestock & $\$ 199.2$ & $\$ 358.8$ & $\$ 221.7$ & $\$ 471.1$ & $\$ 139.8$ & $\$ 242.8$ & $\$ 310.4$ & $\$ 515.2$ & $\$ 117.7$ & $\$ 246.2$ & $\$ 124.7$ & $\$ 231.9$ & $\$ 87.2$ & $\$ 124.9$ & $\$ 136.5$ & $\$ 229.4$ \\
\hline Agriculture-Related Manufacturing & $\$ 498.5$ & $\$ 802.0$ & $\$ 1,277.5$ & $\$ 2,914.9$ & $\$ 10.9$ & $\$ 18.2$ & $\$ 424.6$ & $\$ 671.9$ & $\$ 39.1$ & $\$ 75.1$ & $\$ 65.8$ & $\$ 120.2$ & $\$ 296.7$ & $\$ 422.3$ & $\$ 26.5$ & $\$ 41.7$ \\
\hline Transportation and Wholesaling & $\$ 250.3$ & $\$ 360.5$ & $\$ 604.6$ & $\$ 1,023.8$ & $\$ 82.8$ & $\$ 101.8$ & $\$ 314.8$ & $\$ 416.2$ & $\$ 86.2$ & $\$ 118.7$ & $\$ 96.0$ & $\$ 125.2$ & $\$ 125.1$ & $\$ 155.7$ & $\$ 93.6$ & $\$ 124.9$ \\
\hline Agri-Tourism & $\$ 3.8$ & $\$ 5.5$ & $\$ 5.3$ & $\$ 9.4$ & $\$ 2.4$ & $\$ 3.0$ & $\$ 5.9$ & $\$ 7.9$ & $\$ 2.3$ & $\$ 3.1$ & $\$ 2.8$ & $\$ 3.7$ & $\$ 2.7$ & $\$ 3.4$ & $\$ 2.9$ & $\$ 3.8$ \\
\hline Total & & $\$ 1,755.5$ & & $\$ 5,141.0$ & & $\$ 440.4$ & & $\$ 1,968.5$ & & $\$ 544.4$ & & $\$ 668.5$ & & $\$ 986.9$ & & $\$ 532.1$ \\
\hline Region Total & & $\$ 5,103.8$ & & $\$ 51,807.9$ & & $\$ 1,114.7$ & & $\$ 4,359.3$ & & $\$ 2,659.3$ & & $\$ 1,914.3$ & & $\$ 2,746.7$ & & $\$ 2,237.4$ \\
\hline Percentage & & $34.4 \%$ & & $9.9 \%$ & & $39.5 \%$ & & $45.2 \%$ & & $20.5 \%$ & & $34.9 \%$ & & $35.9 \%$ & & $23.8 \%$ \\
\hline
\end{tabular}

Table 5.5: 2017 Economic Impact of Agriculture in Nebraska Employment By Region

\begin{tabular}{|c|c|c|c|c|c|c|c|c|c|c|c|c|c|c|c|c|}
\hline \multirow[b]{2}{*}{ Industry } & \multicolumn{2}{|c|}{ Central } & \multicolumn{2}{|c|}{ East } & \multicolumn{2}{|c|}{ North } & \multicolumn{2}{|c|}{ Northeast } & \multicolumn{2}{|c|}{ Northwest } & \multicolumn{2}{|c|}{ South } & \multicolumn{2}{|c|}{ Southeast } & \multicolumn{2}{|c|}{ Southwest } \\
\hline & Direct & Total & Direct & Total & Direct & Total & Direct & Total & Direct & Total & Direct & Total & Direct & Total & Direct & Total \\
\hline Crops & 5,885 & 9,162 & 12,064 & 21,542 & $4,159.8$ & $4,999.1$ & 10,036 & 13,964 & $3,806.5$ & $5,195.0$ & $5,085.3$ & $7,373.5$ & $8,287.1$ & $11,381.2$ & 5,037 & 6,936 \\
\hline Livestock & 7,453 & 11,878 & 7,362 & 12,519 & $5,282.7$ & $8,574.0$ & 10,158 & 15,553 & $4,618.3$ & $7,955.8$ & $4,488.9$ & $7,326.3$ & $3,090.0$ & $4,214.7$ & 5,146 & 7,801 \\
\hline Agriculture-Related Manufacturing & 9,022 & 16,361 & 18,635 & 45,493 & 240.1 & 412.6 & 7,261 & 12,622 & 696.2 & $1,349.6$ & $1,181.6$ & $2,291.8$ & $5,053.2$ & $8,619.3$ & 466 & 876 \\
\hline Transportation and Wholesaling & 3,280 & 6,090 & 7,864 & 16,000 & 951.6 & $1,570.0$ & 4,246 & 6,892 & $1,021.0$ & $1,799.4$ & $1,079.6$ & $1,857.8$ & $1,477.6$ & $2,387.1$ & 1,068 & 1,895 \\
\hline Agri-Tourism & 195 & 242 & 269 & 357 & 121.4 & 142.0 & 302 & 355 & 117.6 & 140.6 & 142.6 & 168.2 & 140.3 & 161.5 & 148 & 174 \\
\hline Total & & $43,732.9$ & & $95,911.2$ & & $15,697.6$ & & $49,387.6$ & & $16,440.4$ & & $19,017.6$ & & $26,763.8$ & & $17,683.2$ \\
\hline Region Total & & $122,302.9$ & & $892,294.8$ & & $28,938.2$ & & $103,316.3$ & & $58,139.7$ & & $49,072.2$ & & $69,268.9$ & & $51,961.4$ \\
\hline Percentage & & $35.8 \%$ & & $10.7 \%$ & & $54.2 \%$ & & $47.8 \%$ & & $28.3 \%$ & & $38.8 \%$ & & $38.6 \%$ & & $34.0 \%$ \\
\hline
\end{tabular}

The 2017 Economic Impact of the Nebraska Agricultural Production Complex $\quad$ Page 41 


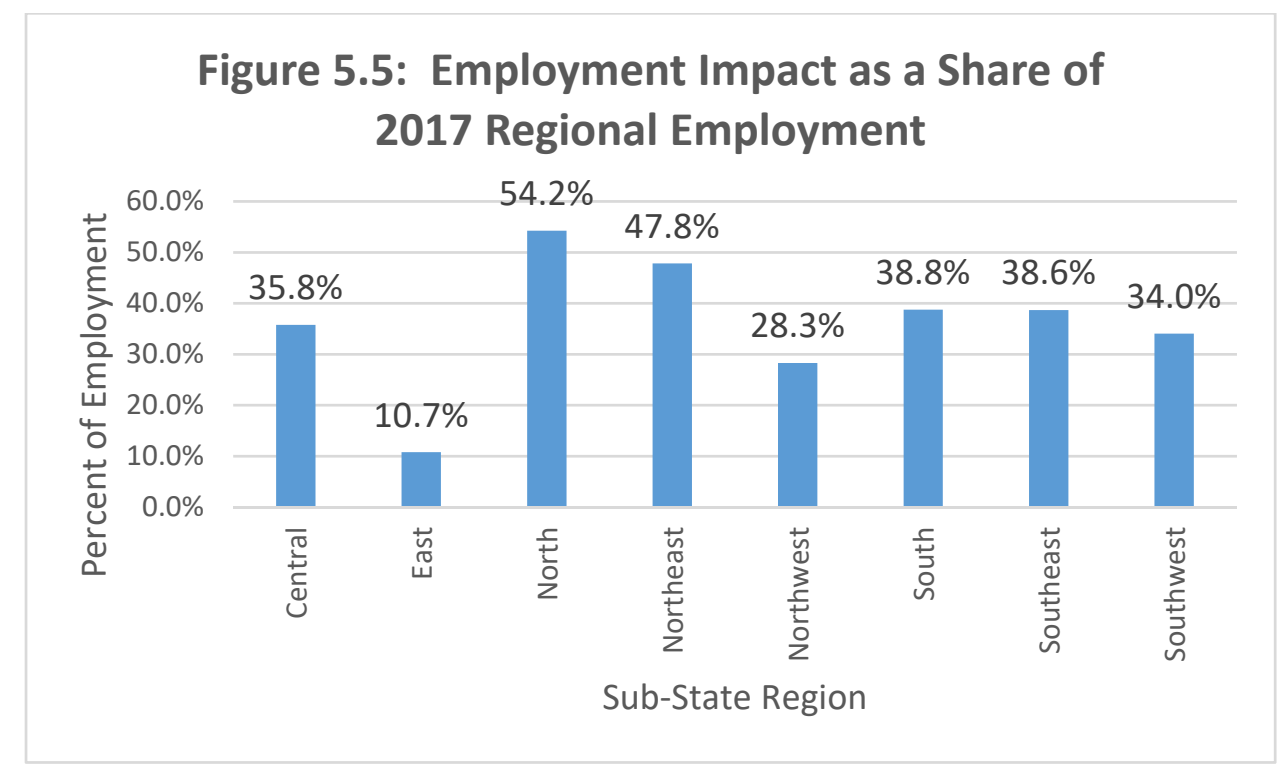




\section{Chapter 6}

\section{Conclusions and Implications}

This study examines the economic impact of Nebraska's agricultural production complex during 2017, the year of the most recent agricultural Census. The complex includes the production, processing, wholesaling, and transportation of agricultural goods. The complex gains a number of advantages from operating in Nebraska including (1) a rich and diverse natural resource endowment conducive to agricultural production;

(2) skilled human capital and management tapping the efficiency gains of modern technology and production science; (3) a centralized location with good transportation infrastructure; and (4) a synergistic system of both crop and livestock enterprises together with related industries.

To understand Nebraska's agricultural production complex, it is useful to first consider the economic activity directly generated and then the basic contribution of the complex in supporting many other businesses and industries which contribute to the state's economy.

In terms of direct economic activity generated by the agricultural production complex in 2017:

- Total dollar volume (business receipts) was $\$ 55.55$ billion in $2017-23.1 \%$ of Nebraska's total activity

- Total gross state product (value-added) was $\$ 12.35$ billion- $-10.4 \%$ of the state's total gross state product

- Direct employment in the complex was over 166,900 Nebraskans $-12.1 \%$ of the Nebraska workforce

- Wages, benefits, and proprietor income earned in direct employment totaled $\$ 6.66$ billion- $-9.3 \%$ of Nebraska labor income

The total economic impact of the agricultural production complex includes a multiplier impact as well as these direct impacts. The multiplier impact refers to the spillover of new sales, employment, and other economic activity to businesses outside of the complex. 
- Total dollar volume (business receipts) was $\$ 81.78$ billion- $-33.9 \%$ of the state's total activity

- Total GSP (value-added) was $\$ 25.70$ billion-21.6\% of Nebraska's total gross state product

- Employment generated totaled 320,600 jobs $-23.3 \%$ of the Nebraska workforce

- Total wages and proprietor's income were $\$ 14.33$ billion- $19.9 \%$ of the State's labor income

The above state-level metrics for the 2017 calendar year show that the agricultural production complex is a key driving force for the Nebraska economy. The predominance of agricultural complex is even larger in many of the sub-state regions of Nebraska.

- The total impact of agricultural production complex accounts for $46.0 \%$ of gross value-added in the Northeast region of Nebraska.

- The impact of the complex accounts for more than $35 \%$ of gross regional product in 4 other regions, Central, South, Southeast and North Nebraska.

- The impact of the complex accounts $23.9 \%$ of gross regional product in Southwest Nebraska, 20.7\%in Northwest Nebraska and 11.2\%in East Nebraska.

Total impacts reflect that the agricultural production complex is a basic industry which spills over significantly into the rest of the state's economy. In fact, the economic multipliers calculated in this analysis suggest that these spillover effects result in direct economic effects being more than doubled for gross state product and labor income, and nearly doubled for employment. This occurred even in a year such as 2017, when commodity prices were low and farm incomes were modest. One implication is that while farm incomes may be volatile, agricultural-related manufacturing, transportation, and wholesaling are more stable, as are multiplier impacts for businesses and workers outside of the production complex.

The importance of the greater agricultural production complex to the state reinforces the importance of sustaining and growing both the production agriculture sector and the broader ag-related business sector. Farm income and farm productivity are critical to the viability of the production agriculture sector. Similarly, farm productivity 
and production are vital to drive the broader sector and generate the added value that helps make agriculture a key component of the state's economy. Investments in research and development that support continued growth in agricultural productivity and a policy environment that facilitates agricultural production and related manufacturing activity are both important for the future success of Nebraska's agricultural production complex. 


\section{References}

IMPLAN. 2020. Available at https://www.implan.com/.

Lamphear, C. 2006. "The Importance of Agriculture and Agribusiness to Nebraska's Economy: 2002. Nebraska Policy Institute. March.

Lamphear, F.C. and M. Turner. 1979. "EC79-871 The Agri Complex : Nebraska's Basic Industry." Historical Materials from University of Nebraska-Lincoln Extension. 4529. Available at http://digitalcommons.unl.edu/extensionhist/4529.

National Agricultural Statistics Service. 2017. “2017 Census of Agriculture.” U.S. Department of Agriculture. Available at https://www.nass.usda.gov/Publications/AgCensus/2017/index.php.

Taylor, R.G., C. Lamphear, and K. Nelson. 1994. "EC94-807 A Measure of Agribusiness on Nebraska's Economy." Historical Materials from University of Nebraska-Lincoln Extension. 1605. Available at https://digitalcommons.unl.edu/extensionhist/1605.

Thompson, E., B. Johnson, and A. Giri. 2012. "The 2010 Economic Impact of the Nebraska Agricultural Production Complex." Department of Agricultural Economics Report No.192, June. Publication available at https://agecon.unl.edu/research/nebraskaag-economic-impact.pdf. Webpage available at https://agecon.unl.edu/research/agriculture-impact.

U.S. Bureau of Economic Analysis. 2020. Data available at www.bea.gov.

Vogt, R., C. Burkhart-Kriesel, R. Cantrell, B. Lubben, L.J. McElravy, and T. Meyer. 2017. "Perceptions of Agriculture and the Economy in Nonmetropolitan Nebraska: 2017 Nebraska Rural Poll Results." Nebraska Rural Poll Research Report 17-1, University of Nebraska-Lincoln. July. Available at ruralpoll.unl.edu/pdf/17ageconomy.pdf. 


\section{Appendix 1}

\begin{tabular}{lcccc}
\hline $\begin{array}{l}\text { Table A.1.4.4A: 2017 Economic Impact (Business Receipts) } \\
\text { Transportation and Wholesaling }\end{array}$ & \multicolumn{4}{l}{ Agriculture Related } \\
\hline Industry & $\begin{array}{c}\text { Total Value } \\
\text { (Millions \$) }\end{array}$ & $\begin{array}{c}\text { Direct Impact } \\
\text { (Millions \$) }\end{array}$ & $\begin{array}{c}\text { Multiplier } \\
\text { (Millions \$) }\end{array}$ & $\begin{array}{c}\text { Total } \\
\text { (Millions \$) }\end{array}$ \\
\hline \hline Farm Supply and Merchandising & $\$ 961$ & $\$ 961$ & $\$ 658$ & $\$ 1,619$ \\
Truck Transportation & $\$ 2,122$ & $\$ 2,122$ & $\$ 1,615$ & $\$ 3,737$ \\
Rail Transportation & $\$ 296$ & $\$ 296$ & $\$ 138$ & $\$ 434$ \\
Equipment Dealers & $\$ 819$ & $\$ 819$ & $\$ 602$ & $\$ 1,421$ \\
\hline Total & $\mathbf{\$ 4 , 1 9 7}$ & $\mathbf{\$ 4 , 1 9 7}$ & $\mathbf{\$ 3 , 0 1 4}$ & $\mathbf{\$ 7 , 2 1 1}$ \\
\hline
\end{tabular}

\begin{tabular}{lccc}
\hline \multicolumn{3}{l}{ Table A.1.4.4B: 2017 GSP (Value-Added) Impact of Agriculture-Related } \\
Transportation and Wholesaling & \multicolumn{3}{l}{} \\
\hline Industry & $\begin{array}{c}\text { Direct } \\
\text { (Millions \$) }\end{array}$ & $\begin{array}{c}\text { Multiplier } \\
\text { (Millions \$) }\end{array}$ & $\begin{array}{c}\text { Total } \\
\text { (Millions \$) }\end{array}$ \\
\hline \hline Farm Supply and Merchandising & $\$ 710$ & $\$ 383$ & $\$ 1,093$ \\
Truck Transportation & $\$ 1,021$ & $\$ 948$ & $\$ 1,969$ \\
Rail Transportation & $\$ 227$ & $\$ 77$ & $\$ 304$ \\
Equipment Dealers & $\$ 657$ & $\$ 348$ & $\$ 1,005$ \\
\hline Total & $\mathbf{\$ 2 , 6 1 4}$ & $\mathbf{\$ 1 , 7 5 6}$ & $\mathbf{\$ 4 , 3 7 1}$ \\
\hline
\end{tabular}

\begin{tabular}{lccc}
\hline $\begin{array}{l}\text { Table A.1.4.4C: 2017 Labor Income Impact of Agriculture-Related } \\
\text { Transportation and Wholesaling }\end{array}$ & $\begin{array}{c}\text { Direct } \\
\text { (Millions } \$ \text { ) }\end{array}$ & $\begin{array}{c}\text { Multiplier } \\
\text { (Millions } \$ \text { ) }\end{array}$ & $\begin{array}{c}\text { Total } \\
\text { (Millions \$) }\end{array}$ \\
\hline Industry & $\$ 397$ & $\$ 221$ & $\$ 617$ \\
\hline \hline Farm Supply and Merchandising & $\$ 757$ & $\$ 561$ & $\$ 1,318$ \\
Truck Transportation & $\$ 110$ & $\$ 46$ & $\$ 156$ \\
Rail Transportation & $\$ 390$ & $\$ 201$ & $\$ 591$ \\
Equipment Dealers & $\mathbf{\$ 1 , 6 5 3}$ & $\mathbf{\$ 1 , 0 3 0}$ & $\mathbf{\$ 2 , 6 8 3}$ \\
\hline Total & & & \\
\hline
\end{tabular}


Table A.1.4.4D: 2017 Employment Impact of Agriculture-Related Transportation and Wholesaling

\begin{tabular}{lccc}
\hline Industry & Direct & Multiplier & Total \\
\hline \hline & & & \\
Farm Supply and Merchandising & 3,613 & 4,670 & 8,283 \\
Truck Transportation & 12,666 & 11,350 & 24,016 \\
Rail Transportation & 601 & 973 & 1,574 \\
Equipment Dealers & 4,109 & 4,281 & 8,390 \\
\hline Total & $\mathbf{2 0 , 9 8 8}$ & $\mathbf{2 1 , 3 7 6}$ & $\mathbf{4 2 , 2 6 4}$ \\
\hline
\end{tabular}

